\title{
Prospects for Alkaline Zero Gap Electrolyte Water Electrolysers for Hydrogen Production
}

\author{
Derek Pletcher \\ School of Chemistry, University of Southampton SO17 1BJ, England \\ and Xiaohong $\mathrm{Li}^{*}$ \\ School of Engineering Sciences, University of Southampton SO17 1BJ, England
}

* Corresponding author. Email: Xh.Li@soton.ac.uk Tel: +44-2380-594905

Fax: +44-2380-594905 


\begin{abstract}
This review makes the case for cheaper and more efficient water electrolysis technology. In particular, the potential advantages of zero gap, alkaline water electrolysers based on hydroxide ion conducting membranes are highlighted. Following a brief introduction into the thermodynamics and kinetics of water electrolysis, recent developments in oxygen evolving anodes, hydrogen evolving cathodes and hydroxide transporting membranes appropriate to such technology are reviewed.
\end{abstract}

\title{
Keywords
}

Hydrogen production; Alkaline water electrolysers; Anion exchange membrane; Zero gap membrane cells; Hydrogen evolution cathode; Oxygen evolution anode 


\section{Introduction}

Water electrolysis is not a new process for the production of hydrogen [1-11]; even 50 years ago, there were a number of industrial plants scattered around the world. Yet, water electrolysis remains a very minor contributor to the total production of hydrogen. In total, some 40 million tons of hydrogen are produced each year and used in the manufacture of ammonia, for the hydrogenation of organics, in petroleum refineries, in metals production, for electronics fabrication, for high temperature flames and for cooling thermal generators $[12,13]$. Presently, > $95 \%$ of this $\mathrm{H}_{2}$ comes from fossil fuel feedstock using high temperature, gas phase reactions such as

$$
\begin{array}{ll}
\mathrm{CH}_{4}+\mathrm{H}_{2} \mathrm{O} \stackrel{\text { catalyst }}{\longrightarrow} 3_{2}+\mathrm{CO} \\
\mathrm{CO}+\mathrm{H}_{2} \mathrm{O} \stackrel{\text { catalyst }}{\longrightarrow} \mathrm{H}_{2}+\mathrm{CO}_{2}
\end{array}
$$

But, in contrast to the technologies based on reactions (1) and (2), water electrolysis provides a clean route to hydrogen from water and, if the electricity comes from renewable sources, the goal is achieved without the consumption of fossil fuel or the emission of $\mathrm{CO}_{2}$ - truly green technology. Also, the hydrogen has a very high purity, $>99.9 \%$ directly from the cell, ideal for some high value added processes such as the manufacture of electronic components.

Hydrogen provides a possible solution to our needs for a sustainable fuel for our future transport requirements and also an approach to the large scale storage of energy. Such scenarios would require a very large expansion in hydrogen production by water electrolysis and it is critical that the hydrogen is produced by green technology. The technology must, however, also be energy efficient and inexpensive. This provides a large driving force for new, improved water electrolysis technology. Existing water electrolysis plants are usually based on cells with an aqueous alkaline electrolyte and a porous separator $[14,15]$. The maximum current density is typically $\sim 0.25 \mathrm{~A} \mathrm{~cm}^{-2}$ and even then its energy efficiency is typically only $\sim 60 \%$. When combined with a fuel cell to provide a method of energy storage, the overall energy efficiency drops below $40 \%$. These shortcomings led to the development of SPE (solid polymer electrolyte) cells with proton conducting membranes such as Nafion ${ }^{\mathrm{R}}$ as the electrolyte and either a zero gap configuration or cells with a fuel cell type membrane electrode assembly (MEA) [3,8,9,11]. While they lead to substantial improvements in the energy efficiency and they have been available, at least as small units, for at least 25 years, such electrolysers have not impacted large scale $\mathrm{H}_{2}$ production. This is largely because of the high cost of both the membranes and the electrocatalysts in the acidic environment. In addition, water electrolysis cells that operate at elevated pressure are also marketed [4,7]; the major customers are the military and space exploration and the main product is commonly the 
pure oxygen for the atmosphere within submarines, space craft etc. Hence, electrolysers suitable for application on a very large scale but fabricated from cheaper components and achieving the essential reduction in cell voltage remains a highly desirable goal. Operation in alkaline conditions opens up the possibility of using non-precious metal electrocatalysts and anode materials in alkali can also give lower overpotentials for $\mathrm{O}_{2}$ evolution than in acid environments; cheaper cell components and lower energy consumption lead to the possibility of cheaper hydrogen production.

An attractive approach is based on the design of zero gap electrolysers with a hydroxide conducting membrane, see figure 1. In such cells the electrodes are contacting the two membrane surfaces so as to minimise the voltage (IR) drop between the electrodes. While zero gap cells with a porous separator can be constructed, they are likely to have a higher voltage drop leading to operation at lower current density and, consequently, larger electrolysis plants. A hydroxide ion conducting membrane also offers the possibilities that (a) rather than being meshes or similar structures pressed against the membrane, the electrodes can be fabricated directly onto the membrane surfaces to give a MEA familiar in fuel cell technology - the technology and fabrication of water electrolysis cells then becomes akin to that for alkaline fuel cells and (b) the cell feed is pure water rather than aqueous alkali since this simplifies auxiliary unit processes and reduces the possibility of corrosion in plant components. Stable, non-precious metal catalysts can be identified. The hydroxide conducting membrane needs to be stable and robust and fabricated from a polymer with a high conductivity for $\mathrm{OH}^{-}$so that the cell can operate at a high current density (maybe $1 \mathrm{~A}$ $\mathrm{cm}^{-2}$ ). So far, it has proved difficult to fabricate such membranes particularly membranes that operate well in contact with pure water and, indeed, it is uncertain whether suitable membranes are yet available on the open market. Acid membranes operate well with pure water feeds so that electron transfer appears to occur directly between the electrode materials and species within the polymer phase. Therefore, it is difficult to see why this problem with hydroxide conducting membranes cannot be solved. Certainly, several companies seem close to producing hydroxide ion conducting membranes with at least some of the required properties. Hence it seems timely to review the advances in alkaline zero gap technology resulting from the recent activity targeted towards upgrading water electrolysis technology. Particularly within energy storage, an attractive concept is the regenerative fuel cell [16,17] with the capability for the production of hydrogen and its conversion back to energy within a single cell; this of course requires an electrode composition and structure allowing energy efficient formation and consumption of both $\mathrm{O}_{2}$ and $\mathrm{H}_{2}$. 
The electrolysis of aqueous brine to give chlorine, sodium hydroxide and hydrogen remains the largest electrolytic process producing hydrogen. Indeed, chlor-alkali plants are ubiquitous throughout the world [4,18] and together produce $\sim 1$ million tons per year of hydrogen despite it being considered a byproduct. But the economics of the chlor-alkali industry depend on the sale of the chlorine and sodium hydroxide as well as the hydrogen; expansion of hydrogen production on the scale being discussed would produce a vast excess of unsaleable chlorine. Moreover, at smaller installations away from chemical plant, the cogeneration of chlorine would preclude it as a 'green' technology. In stark contrast to water electrolysis, however, the past forty years has seen a revolution in chlor-alkali technology with the development of both membranes and electrode catalysts specifically for the industry and the subsequent introduction of membrane cells. The same period has seen a massive activity related to proton conducting membrane fuel cells [19,20] and there have been substantial improvements in the performance of such fuel cells resulting from upgrading the cell configuration, the membrane and the electrocatalysts. The advances with respect to catalysts result from changes in composition and methods to disperse the catalysts over inert substrates, generally carbon based. They have led to significant reductions in catalyst loadings as well as lower overpotentials and greater stability to losses of both catalyst mass and catalyst surface area in operating conditions. While, unfortunately, the advances in chloralkali technology and proton exchange membrane (PEM) fuel cells may not be directly applicable to water electrolysis, they certainly provide guidance as how alkaline SPE technology might be developed.

\section{Scaling our Thinking}

As we look to the future and consider water electrolysis for transport and energy storage application, it is critical that we understand the target being set. It will certainly be essential to have a buffer, based on electrochemical or other technology, between renewable sources of energy and the consumer; the renewable sources will produce energy only under favourable natural conditions (eg. during daylight, when the wind blows) while consumers expect to have access to electricity available at all times. On the other hand, it is necessary to recognise the scale of operations that is being discussed [13,21]. Table 1 compares the possible size of water electrolysis plants for various applications and compares it with some existing technology. The calculations shown in the table assume that all the electricity produced by the single power generation plant is to be stored and should be taken only as an indication of the demand for storage capacity - but in the USA there are the equivalent of 900 
such power generation plants and, overall, it may be essential to have storage capacity equivalent to 30 - $50 \%$ of peak consumer demand in an 'all renewable' energy economy. This table also requires a number of assumptions about the current density of operation of a water electrolysis plant (in fact taken as $0.5 \mathrm{~A} \mathrm{~cm}^{-2}$ ), the way the car is used etc and is intended only as a guide. There can, however, be no doubt about the conclusions. Firstly, the storage of energy by electricity generating companies through the generation of hydrogen will require the construction of plants much larger than any electrolysis plants presently in existence. In fairness, it should be recognised that a similar calculations based on batteries would be worse since water electrolysis cells operate at $0.2-1.5 \mathrm{~A} \mathrm{~cm}^{-2}$ while redox flow batteries are usually charged at $<0.05 \mathrm{~A} \mathrm{~cm}^{-2}$ and lithium ion batteries commonly below $0.001 \mathrm{~A} \mathrm{~cm}^{-2}$. Less intensive storage looks more promising. A plant to store the electricity from a wind farm would appear more manageable since although still a large electrolysis plant, it is one at least comparable to existing facilities; also it should be recognised that a large $\mathrm{Cl}_{2} / \mathrm{NaOH}$ plant handles an equivalent amount of hydrogen, even if it is considered the byproduct. For a fuel station to serve a small town, the scale technology become much more modest and it is possible to envisage the electrolysis in a single cell stack. To provide fuel for a single car, several companies can already provide a small unit to produce the hydrogen and the issues become safe storage and cost. Widespread adoption of electric vehicles would, however, also require some reinforcement of the local distribution network to handle the increased demand for electricity. All the future applications of water electrolysis will require improvements in energy efficiency, reliable, long lived and cheap cell components and innovation in cell design and manufacture.

The US National Renewable Energy Laboratory regularly reviews the economics of hydrogen production by water electrolysis and considers issues such as the integration of an electrolysis plant with a wind farm, for example [13,21]. It has been shown clearly that for small systems, the dominant factor in determining the cost of $\mathrm{H}_{2}$ is the cost of the electrolysis cells while, in contrast, for large systems the cost of electricity and the value of the hydrogen dominate the discussion.

\section{Factors Influencing the Cell Voltage}

In order to convert water into hydrogen and oxygen, it is necessary to apply a voltage between two electrodes to drive the overall cell reaction

$$
2 \mathrm{H}_{2} \mathrm{O} \longrightarrow 2 \mathrm{H}_{2}+\mathrm{O}_{2}
$$

In alkaline solution, the corresponding cathode and anode reactions are 


$$
\begin{aligned}
& 4 \mathrm{H}_{2} \mathrm{O}+4 \mathrm{e}^{-} \longrightarrow 2 \mathrm{H}_{2}+4 \mathrm{OH}^{-} \\
& 4 \mathrm{OH}^{-}-4 \mathrm{e}^{-} \longrightarrow \mathrm{O}_{2}+2 \mathrm{H}_{2} \mathrm{O}
\end{aligned}
$$

The cell voltage will have contributions from

(a) the need to supply energy in order to drive the cell chemical change. Water is very stable at practical temperatures and hence there must be a significant energy input to satisfy the thermodynamics of the unfavourable, overall chemical change, reaction (3).

(b) the overpotentials to enhance the rates of the electrode reactions, reactions (4) and (5) to the desired high rate.

(c) to drive the current through the cell contacts, electrodes and interelectrode gap, whether aqueous electrolyte or membrane.

The cell voltage is therefore given by an equation such as

$$
-E_{\text {cell }}=\Delta E_{e}-\left|\eta_{a}\right|-\left|\eta_{c}\right|-I R
$$

where $\Delta E_{e}$ is the difference in the equilibrium potentials for the two electrode reactions, $\eta$ are the overpotentials at the anode and cathode respectively, $I$ is the cell current and $R$ the resistance of the cell. It should be noted that the overpotential and $I R$ terms increase with current density and should be regarded as inefficiencies leading to low grade heat. Minimising the overpotentials depends on the availability of good electrocatalysts while minimising the $I R$ term is dependent on good electrochemical engineering, ie. minimising the interelectrode gap, ensuring that only high ionic conductivity materials are between the electrodes and ensuring that the evolved gas effectively escapes the interelectrode gap.

The energy efficiency for the cell is given by

$$
\text { Energy efficiency }=\frac{\Delta E_{e}}{E_{\text {cell }}} 100
$$

Typical values are in the range $40-60 \%$ and the much of the present research and development seeks to increase the efficiency significantly as well as minimising the cost of the cell and all cell components.

\section{The Thermodynamics of Water Electrolysis}

In all water electrolysis cells operating below a temperature of $373 \mathrm{~K}$, the overall chemical change is

$$
2 \mathrm{H}_{2} \mathrm{O}(\mathrm{l}) \rightleftarrows 2 \mathrm{H}_{2}(\mathrm{~g})+\mathrm{O}_{2}(\mathrm{~g})
$$

The equilibrium lies far to the left - water appears completely stable. The conversion requires the input of energy and in electrolysis this is achieved by applying a potential difference 
between two electrodes. Under standard conditions where the temperature is $298 \mathrm{~K}$ and the gases are present at a pressure of 1 atmosphere, the standard enthalpy, $\Delta H^{o}$, for reaction (8) is $+286 \mathrm{~kJ} / \mathrm{mole}$ of $\mathrm{H}_{2}$ and the Gibbs energy, $\Delta G^{o}$, is $+238 \mathrm{~kJ} /$ mole of $\mathrm{H}_{2}$. The significant difference arises because the electrolysis leads to the conversion of a liquid to two gases and hence to a large increase in the entropy of the system. In an isolated system, it would be necessary to apply a potential difference, $\Delta E_{e}^{o}$, of $-1.48 \mathrm{~V}\left(-\Delta H^{o} / 4 F\right)$ in order to satisfy the thermodynamic requirements. In practice, however, it is not necessary to introduce all the energy in the form of electrical energy and the increase in entropy can be achieved by absorption of heat from the surroundings (also, the inefficiencies in a practical cell, see above, will appear as heat that can contribute to this entropy gain). Then the potential difference required is then only $-1.23 \mathrm{~V}\left(-\Delta G^{o} / 4 F\right)$. When operating away from standard conditions, the equilibrium cell voltage must be calculated from the Nernst equations for the two electrode reactions and leading to

$$
\Delta E_{e}=\Delta E_{e}^{o}+\frac{R T}{4 F} \ln \frac{a_{H_{2}}{ }^{2} a_{O_{2}}}{a_{H_{2} O}{ }^{2}}
$$

where $a$ are the activities of the reactant and products.

It should be noted that the thermodynamics of a water electrolysis cell are independent of $\mathrm{pH}$. As can be seen from the Nernst equation for the two electrode reactions, the equilibrium potential for both the anode reaction and the cathode reaction shift negative with increase in $\mathrm{pH}$ at the same rate (both electrode reactions (4) and (5) involve $1 \mathrm{H}^{+} / \mathrm{e}^{-}$and hence at $298 \mathrm{~K}$, the shift will be $-59.6 \mathrm{mV} / \mathrm{pH}$ unit). Hence the difference in equilibrium potentials, the equilibrium cell voltage, is independent of $\mathrm{pH}$. In fact this is immediately clear since the overall cell reaction, reaction (8), does not lead to the consumption or production of protons or hydroxide ion.

In addition, temperature has little influence on the thermodynamics. For example, at $353 \mathrm{~K}$, a typical operating temperature for some cells, the equilibrium cell voltage is $-1.19 \mathrm{~V}$, only a $\sim 4 \%$ decrease for a $55 \mathrm{~K}$ increase in temperature. Above $373 \mathrm{~K}$, the cell reaction becomes

$$
2 \mathrm{H}_{2} \mathrm{O}(\mathrm{g}) \rightleftarrows 2 \mathrm{H}_{2}(\mathrm{~g})+\mathrm{O}_{2}(\mathrm{~g})
$$

but, from the viewpoint of thermodynamics, the advantage of increasing the temperature remains small. For example, to obtain an equilibrium cell voltage of $-1.00 \mathrm{~V}$, the temperature must be increased to $1000 \mathrm{~K}$. 
On the other hand, there may be good reason to increase the temperature. Higher temperature leads to substantially improved kinetics for both the electrode reactions and also an increase in the conductivity of the electrolyte, thereby decreasing IR drop. But the use of a higher temperature places more demands on materials - increasing the temperature will increase rates of corrosion and/or chemical decomposition and may also degrade mechanical properties.

\section{The Kinetics of the Electrode Reactions}

The rate (ie. current density, $j$ ) of both the hydrogen and oxygen evolution reactions can be described by a Tafel type equation [22]

$$
\log |j|=\log j_{o}+\left|\frac{\eta}{\beta}\right|
$$

where $j_{o}$ is the exchange current density (ie. the equal, partial anodic and cathodic current densities at the equilibrium potentials), $\eta$ the applied overpotential $\left(=E-E_{e}\right)$ and $\beta$ the Tafel slope.

The kinetics of both hydrogen and oxygen evolution vary strongly with electrode material (electrocatalyst). The values of exchange current density vary by a factor of $10^{10}$ while the variation of Tafel slope may lead to a variation of current density by a factor of 10 every $30 \mathrm{mV}, 40 \mathrm{mV}, 60 \mathrm{mV}$ or every $120 \mathrm{mV}$ (depending on mechanism) [23-29]. In consequence the overpotentials at each electrode can vary from $<250 \mathrm{mV}$ to $>2000 \mathrm{mV}$ at the operating current density of water electrolysers. The performance of electrocatalysts certainly depends on the composition of the catalyst and its surface area but may also be a function of the catalyst microstructure (eg. the density of specific surface sites) and also the support for the catalyst.

In general, in this review, electrocatalysts will be compared using measured overpotentials at fixed current density. The use of exchange current density is avoided because the values in the literature are subject to large errors. In addition to factors such as pretreatments and experimental procedures, the determination of the exchange current density requires extrapolation of current density vs potential data over hundreds of millivolts using Tafel slopes that are poorly defined or even 'imaginary'.

The mechanisms and kinetics of both hydrogen evolution [23-26] and oxygen evolution [26-29] have been discussed extensively. In general, the kinetics of hydrogen evolution can be rapid so that the reaction takes place at many surfaces with only a small 
overpotential. In contrast, the kinetics of oxygen evolution are generally poor so that the anode reaction usually requires a substantial overpotential. Indeed, this overpotential is usually the major inefficiency in water electrolysis cells. The following two sections discuss hydrogen and oxygen evolution in conditions appropriate to an alkaline water electrolyser.

\section{Cathodes}

Hydrogen evolution is probably the most extensively studied electrode reaction [2326]. While it is clear that the performance of cathode catalysts for this reaction depends on the composition of the catalyst, its microstructure and its surface area, it is possible to identify catalysts that allow efficient hydrogen evolution. In acid solution, the preferred materials are Pt or Pt alloys in a high area form, a metal black or metal nanocentres highly dispersed on a carbon powder support. One of the driving forces for the development of alkaline water electrolysers has always been the possibility of using cheaper, non-precious metal catalyst materials and this has not changed.

Unfortunately, however, the literature can be a poor guide to the performance of cathodes in operating water electrolysers. This is for several reasons. Firstly, much of the literature relates to room temperature whereas water electrolysers generally operate at 333 $373 \mathrm{~K}$ where the rate of hydrogen evolution may be higher by a factor $>100$. The increased temperature alone may lead to a decrease in overpotential of maybe $200 \mathrm{mV}$. Secondly, because of concerns about IR distortion of experimental data, the kinetics of hydrogen evolution are generally discussed in terms of Tafel slopes and exchange current densities measured in a current density range $\left(<0.01 \mathrm{~A} \mathrm{~cm}^{-2}\right)$ well below that employed for water electrolysis $\left(0.2-2 \mathrm{~A} \mathrm{~cm}^{-2}\right)$ when it is possible that quite different mechanisms and kinetics operate. Indeed, the literature often proposes different Tafel slopes at 'low' and 'high' current densities although it is often unclear as to whether the conclusions results from the experimental difficulties of measuring reliable Tafel slopes at high current densities (eg. gas blanketing of the surface, IR drop). Thirdly, structure and real surface area are as important as the composition of the catalyst layer in determining its activity; this is, of course, widely recognised but it still makes difficult the comparison of materials studied in different laboratories. Moreover, long term stability and stability of performance are issues seldom addressed in the academic literature. In addition to corrosion (in all conditions met - ie. onload, on open circuit and during switching out cells), the performance can be lost [30] due to (a) the absorption of hydrogen within the catalyst structure (b) the adsorption of organics (from impurities in the water/ electrolytes or extracted from the membrane or polymer 
components) onto the catalyst surface or (c) deposition of metals (eg. Fe), less active as a catalyst, onto the cathode surface - such metal ions are most likely to arise from impurities in $\mathrm{NaOH} / \mathrm{KOH}$ if the cell medium is aqueous alkali rather than pure water or corrosion of metal components in the electrolyser system. In this review, the discussion of cathode materials will focus only on those materials studied in conditions close to those found in an alkaline SPE water electrolyser. Much can be learnt from experience in the chlor-alkali industry [31] where commercial cathode coatings operate at low overpotential with lifetimes of several years. Zero gap cells are common and the cathode reaction is also hydrogen evolution in a strongly aqueous alkali at temperatures (333 -363 K) similar to those employed in a water electrolyser. If the water electrolyser employs a $\mathrm{NaOH} / \mathrm{KOH}$ medium, the conditions are virtually identical while if the medium is pure water the environment at the cathode remains similar, if perhaps less alkaline.

Traditional alkaline water electrolysers employ iron or steel cathodes but these are not sufficiently stable to corrosion at high alkali concentrations and elevated temperatures. Indeed, because of the adverse influence of Fe species in the catholyte, it is to be expected that water electrolysis cells will be fabricated from materials not containing iron. Certainly, the more expensive nickel is now universally used as the substrate material despite itself being a less active catalyst than iron or steel. Nickel is also a common component of the cathode coating. The Tafel slope for smooth nickel in $\mathrm{KOH}$ or $\mathrm{NaOH}$ solutions at room temperature is $120 \mathrm{mV}$ indicating the initial electron transfer from the cathode to water molecules as the rate determining step in hydrogen evolution [24,32]. The overpotential for hydrogen evolution is typically $\sim 300-400 \mathrm{mV}$ at the current densities desired in water electrolysers, far too large for modern electrolysers and hence the focus on the development of electrocatalytic coatings. Nickel is also an example of a metal where absorption of hydrogen into the nickel lattice leads to deactivation although, fortunately, the increase in overpotential is much less at temperatures in the $343-373 \mathrm{~K}$ range. The influence of temperature on the kinetics of hydrogen evolution at nickel has been reported by several groups [33-35] and the overpotential for hydrogen decreases by $200 \mathrm{mV}$ in going from $293 \mathrm{~K}$ to $363 \mathrm{~K}$.

Even as early as 1980, the appropriate catalytic coatings for cathodes in a chlor-alkali membrane cell had been developed by commercial electrode manufacturers. Four types of coating were marketed (i) high surface area platinum or other precious metals [36-39] (ii) ruthenium dioxide [40,41] (iii) Raney $\mathrm{Ni}[42,43]$ and (iv) $\mathrm{Ni}$ alloys, particularly NiMo $[39,44,45]$. All claimed similar overpotentials for hydrogen evolution, $50-100 \mathrm{mV}$ at a current density of $0.5 \mathrm{~A} \mathrm{~cm}^{-2}$. As far as we are aware, all four types of coating can still be 
purchased although little specific information on the manufacturing technology or performance data has been published by the cathode suppliers.

It is, of course, generally, recognised that, at all $\mathrm{pH}$, the precious metals are excellent catalysts for $\mathrm{H}_{2}$ evolution. In water electrolysis cells, the challenge is to present the precious metal(s) as a high area coating onto a nickel substrate in the form of a plate or, more commonly, a mesh and at an acceptable cost (ie. a low loading). Most commonly, the coating is deposited by electroplating or, more cheaply, by immersion plating using the Ni substrate itself as the reducing agent,

$$
2 \mathrm{Ni}+\mathrm{Pt}(\mathrm{IV}) \longrightarrow \mathrm{Pt}+2 \mathrm{Ni}(\mathrm{II})
$$

or by thermal decomposition of a sprayed platinum metal solution. Johnson Matthey [37,38] recommend a PtRu alloy with a loading of $0.30-0.35 \mathrm{mg} \mathrm{cm}^{-2}$ of Pt and $0.1-0.15 \mathrm{mg} \mathrm{cm}^{-2}$ of $\mathrm{Ru}$, prepared by immersion plating. In common with all coating procedures, the $\mathrm{Ni}$ substrate is pretreated; Johnson Matthey used a degreasing solution followed by sandblasting and acid etching. The coating was then applied in a single, room temperature operation by dipping the cathode into an acid solution of the precious metal chlorides. The adhesion of the coating is excellent. Initially, the overpotential for hydrogen evolution in $35 \% \mathrm{NaOH}$ at 363 $\mathrm{K}$ is $\sim 50 \mathrm{mV}$ at a current density of $0.3 \mathrm{~A} \mathrm{~cm}^{-2}$ but this rapidly rises to $\sim 100 \mathrm{mV}$ unless the coating undergoes a post-treatment [38]. With precious metal cathodes, this rise in overpotential is commonly observed and has been attributed to poisoning by iron and/or organics [30]. Later workers have used similar techniques to prepare $\mathrm{Ru}$ on $\mathrm{Ni}[46,47]$ and Ir on Ni [47] cathodes and undertaken more fundamental studies. They report overpotentials down to $50 \mathrm{mV}$ at a current density of $0.1 \mathrm{~A} \mathrm{~cm}^{-2}$ even at room temperature and also Tafel slopes close to $40 \mathrm{mV}$ to confirm that $\mathrm{H}_{2}$ evolution occurs via mechanisms involving $\mathrm{H}$ atoms adsorbed on the metal surface. They also report the advantage of using an electroplated $\mathrm{Ni}$ layer rather than a bulk metal substrate as this has a much higher surface area. Antozzi et al [48] report performance data for some thermally prepared Pt coatings on nickel, see figure 2. These coatings are prepared following a commercial procedure and these Pt based catalysts do show very low overpotentials.

The alternative approach to applying precious metals in water electrolysis cathodes is to use the precious metal dispersed over a high area carbon support in a fuel cell type electrode $[19,20,28,49]$. Usually the pre-prepared precious metal on high area carbon is mixed into an ink with other components such as PTFE (or Nafion for acid systems) and/or a surfactant in a solvent and applied (by spraying, brushing or screen printing) as a thin layer either directly onto the membrane or onto a carbon paper support. Practical gas diffusion 
electrodes may be multilayered structures with a gas diffusion layer formed from larger carbon particles so that it has larger pores as well as a catalyst layer. Up to now, this approach has not been common in SPE or zero gap alkaline water electrolysis cells but may become more important as higher performance alkaline membranes become available.

In practice, ruthenium dioxide is a very effective electrocatalyst for hydrogen evolution in alkaline solutions. At first sight, however, it is an unlikely candidate for practical application [41]. Firstly, examination of the Pourbaix diagram [50] shows that no oxide of ruthenium is thermodynamically stable at the potentials for $\mathrm{H}_{2}$ evolution. Secondly, one does not normally associate irreversible reactions with good catalysis; $\mathrm{RuO}_{2}$ layers neither take up the equilibrium potential of the $\mathrm{H}_{2} \mathrm{O} / \mathrm{H}_{2}$ couple when exposed to hydrogen or catalyse the oxidation of hydrogen because $\mathrm{H}_{2}$ is not dissociatively adsorbed on its surface. The stability of bulk ruthenium dioxide to reduction has been attributed to hydroxylation of the outer layers, thus producing a barrier layer only reducible at very negative potentials where high energy metallic species can be formed [51]. There is, however, clear evidence [41,51] from periodic cyclic voltammetry that a $\mathrm{RuO}_{2}$ layer does change during extended $\mathrm{H}_{2}$ evolution at its surface but the changes to the layer do not increase the overpotential for $\mathrm{H}_{2}$ evolution.

Ruthenium dioxide layers with high surface areas on nickel substrates are fabricated by three types of procedure (a) the thermal decomposition of alcohol solutions of $\mathrm{RuCl}_{3}$ [41,52] using methods familiar for the fabrication of dimensionally stable anodes [53] - such layers may also contain oxides of elements such as $\mathrm{Ti}, \mathrm{Nb}, \mathrm{Zr}$ to further improve their long term stability, (b) the inclusion of $\mathrm{RuO}_{2}$ nanopowder into electroplated nickel [54-58] layer or (c) inclusion of $\mathrm{RuO}_{2}$ into a ruthenium layer formed by immersion plating [59]. In most cases, the Ni substrate is pretreated by sand blasting and acid etching. There is general agreement that the $\mathrm{RuO}_{2}$ coatings give an overpotential for $\mathrm{H}_{2}$ evolution of $<100 \mathrm{mV}$ at a current density of $0.3 \mathrm{~A} \mathrm{~cm}^{-2}$ in $\mathrm{NaOH} / \mathrm{KOH}$ solutions at $363 \mathrm{~K}$ and that $\mathrm{H}_{2}$ evolution gives a Tafel slope in the range $30-60 \mathrm{mV}$, most commonly $40 \mathrm{mV}$. Although not quite as active as fresh precious metal cathodes [48,59], eg. see figure 2, the performance of ruthenium dioxide coatings is very stable over very long periods in conditions of $\mathrm{H}_{2}$ evolution. Its surface does not support the reduction of metal ions to metals and has a lower tendency than metal cathodes to adsorb organics. Also the coating is not harmed by the current reversals that can occur when the cell is taken off line [48,55,59].

Nickel had long been considered as a cathode material for water electrolysis and chloralkali cells. An obvious way to improve the performance of $\mathrm{Ni}$ based cathodes was to fabricate high surface area structures. Even sandblasting the surface of nickel leads to an $\sim 50$ 
$\mathrm{mV}$ decrease in the hydrogen evolution overpotential over the current density range of $0.1-$ $1.0 \mathrm{~A} \mathrm{~cm}^{-2}$. With the application of Raney nickel, a much larger improvement was found and the 1970s and 1980s saw a substantial number of publications [24,34,60-62]. Such cathodes have been prepared by methods such as sintering and electroplating but the most successful method involves the encapsulation of $\mathrm{NiAl}$ or NiZn nanopowder in an electroplated $\mathrm{Ni}$ layer after which the $\mathrm{Al}$ or $\mathrm{Zn}$ dissolves in $\mathrm{KOH} / \mathrm{NaOH}$ electrolyte to give a very high area surface; oxides of metals such as $\mathrm{Ti}, \mathrm{Zr}$ and $\mathrm{Nb}$ have been added to improve the properties of the layer. Such electrodes gave a decrease in overpotential compared to smooth $\mathrm{Ni}$ of $\sim 200 \mathrm{mV}$ with overpotentials of $\sim 100 \mathrm{mV}$ at $0.3 \mathrm{~A} \mathrm{~cm}^{-2}$. The Tafel slope also decreased from $120 \mathrm{mV}$ on smooth $\mathrm{Ni}$ to $40 \mathrm{mV}$ on Raney $\mathrm{Ni}$; the mechanism is changing to one where adsorbed hydrogen is an intermediate. Tanaka et al [63] have reported the influence of the Ni:Al ratio in the Raney $\mathrm{Ni}$ and find the lowest overpotential for $\mathrm{H}_{2}$ evolution when there is a high $\mathrm{Al}$ content. Raney Ni electrodes are not stable to current reversal on taking a cell off load but Yoshida and Morimoto [64] have proposed a more complex structure where both a Raney Ni alloy powder and $\mathrm{a}_{2}$ absorbing alloy powder were occluded into an electroplated Ni layer. Such surfaces gave a further slight decrease in overpotential but also protected the layer from current reversal. The oxidation of the $\mathrm{H}_{2}$ adsorbed in the alloy occurs preferentially to the oxidative dissolution of the nickel on current reversal and hence avoids loss of surface area leading to a higher overpotential.

While molybdenum shows some tendency to dissolve in hot, concentrated $\mathrm{KOH} / \mathrm{NaOH}$, NiMo alloys are thought to have additional mechanisms for catalysis of hydrogen evolution, over and above formation of a porous Raney nickel structure. The 1980s again saw intensive studies of NiMo electrocatalyst layers [24] and surfaces were prepared by thermal decomposition followed by hydrogen reduction [34,44,45], electrodeposition of NiMo layers [65-67] sometimes as a NiMoCd alloy as this gave a high surface area [67], ball milling of $\mathrm{Ni}$ and Mo nanopowders to form alloy particles followed by pressing to give an electrode $[68,69]$ and low pressure plasma spraying of NiAlMo alloy powders followed by leaching [70-72]. The papers by Brown et al [44,45] suggests that their alloy coating prepared by thermal decomposition and reduction contained $13 \%$ Mo. The coating had a face centred cubic structure with random replacement of $\mathrm{Ni}$ atoms by Mo atoms where the mean lattice parameter was $0.358 \mathrm{~nm}$ compared to $0.352 \mathrm{~nm}$ for pure nickel. SEM showed the layer to have a 'cracked, dried mud' appearance, see figure 3(a) unchanged by very long electrolysis (3000 hours) at $0.5 \mathrm{~A} \mathrm{~cm}^{-2}$ in $30 \% \mathrm{NaOH}$ at $343 \mathrm{~K}$ [67]. Other preparations lead to layers with quite different morphologies, (the low pressure plasma spraying of NiAlMo 
alloy followed by leaching led to a 'cauliflower' morphology, see figure 3(b) [70]) but similar overpotentials for $\mathrm{H}_{2}$ evolution were observed and the Tafel slopes were $40-60 \mathrm{mV}$. The papers by both Brown et al [44,45] and Schiller et al [71] confirm the outstanding performance of the NiMo alloys. Overpotentials are very low, $\sim 60 \mathrm{mV}$ at $0.5 \mathrm{~A} \mathrm{~cm}^{-2}$ in $30 \%$ $\mathrm{NaOH}$ at $343 \mathrm{~K}$ and this performance is maintained over many thousand hours even when the regime includes switching out the cell and variation of the current load. Hu et al $[73,74]$ have, however, advocated inclusion of a hydrogen absorption alloy in the coating to act as a buffer to current reversal on switching out the cell. NiMo alloys certainly seem to be the cathode electrocatalyst of choice for alkaline water electrolysers particularly if precious metals are to be avoided.

In order to consider their suitability in zero gap electrolysis cells with a hydroxide conducting membrane, $\mathrm{Li}$ and Pletcher [75] have compared the performance of several cathode materials, see figure 4 . The cathode coatings were a commercial $\mathrm{RuO}_{2}$ coating and high surface area Pt, Ni and NiMo coatings deposited using sputtering on a fine $\mathrm{Ni}$ mesh and these are compared with the uncoated mesh in the figure. In $4 \mathrm{M} \mathrm{NaOH}$ at $333 \mathrm{~K}$, the Pt cathode again shows the best performance but both the $\mathrm{RuO}_{2}$ and the alloy coatings are almost as good and all allow current densities in excess of $1 \mathrm{~A} \mathrm{~cm}^{-2}$ with only a moderate overpotentials. The Ni containing materials showed no significant increase in overpotential over a 10 day period but Pt showed an increase of $150 \mathrm{mV}$ over a 1 day timescale when tested in a zero gap electrolysis cell with a hydroxide conducting membrane, probably due to adsorption of trace organics in the system.

\section{Anodes}

The overpotential for oxygen evolution at the anode is always large compared to the overpotential at the cathode. No electrocatalysts developed up until now can be considered entirely satisfactory and, in consequence, there remain intensive efforts into developing lower overpotential and more stable electrocatalysts for oxygen evolution. Because of the significant overpotentials required for both oxygen evolution and oxygen reduction, even at the best electrocatalysts, the potential for anodic oxygen evolution is substantially positive to that for cathodic oxygen reduction. This has two consequences (a) even materials nominally discussed as metals are, in fact, covered by an oxide layer (b) at the more positive potential, the driving force for corrosion is higher and corrosion of both the electrocatalyst and the catalyst support are major concerns for water electrolysis cell technology (even when they are stable in fuel cell cathodes). In addition, because of this difference in potential and the complex 
mechanisms involved in oxygen evolution/reduction, (unlike hydrogen evolution/oxidation) the electrocatalysts for oxygen evolution and reduction can be very different.

For the same reasons as stated at the beginning of the section on cathodes, the vast academic literature $[11,26-29,41]$ on anodes for oxygen evolution is, at best, a guide. It is, however, clear that (a) the kinetics of oxygen evolution are never fast (b) it is a complex, multistep reaction involving at least four electron transfers and four proton transfer steps (c) the overpotential for oxygen evolution can depend strongly on the anode material, surface state and temperature. In this review, the focus will be on material for alkaline cells at temperatures in the range $333-393 \mathrm{~K}$ and able to support current densities $>0.5 \mathrm{~A} \mathrm{~cm}^{-2}$. Even with this limited goal, differences in experimental procedures makes difficult comparisons between papers; different groups use different reference electrodes and conversions to other scales while the working electrodes vary from well constructed gas diffusion electrodes to electrode coatings fabricated using diverse procedures.

One major advantage of alkaline conditions is that non-precious metal materials including nickel, cobalt and steels, can be stable. Moreover, in early work [76,77], precious metals were reported to have little or no superiority to nickel for oxygen evolution in alkaline solution. When $\mathrm{Pt}, \mathrm{Pd}, \mathrm{Rh}$, and $\mathrm{Ni}$ were electrodeposited onto $\mathrm{Ni}$ foam and the resulting coatings tested in a water electrolysis cell at a current density of $0.2 \mathrm{~A} \mathrm{~cm}^{-2}$ in $30 \% \mathrm{KOH}$ electrolyte at $363 \mathrm{~K}$, the cell voltages were $\mathrm{Rh}(1.72 \mathrm{~V}), \mathrm{Pd}(1.74 \mathrm{~V}), \mathrm{Ni}(1.75 \mathrm{~V})$, and Pt $(1.80 \mathrm{~V})$. Miles et al. [77] reported about equal activities for Ir, Pt, $\mathrm{Rh}$, and $\mathrm{Pd}$ electrodes while suggesting that Ni was slightly better. In later work [78], they prepared various precious metal oxide electrodes by a thermal decomposition method and found that in $30 \% \mathrm{KOH}$ at $353 \mathrm{~K}$ the effectiveness of these oxide electrodes for oxygen evolution decreases in the order $\mathrm{Ru}>\mathrm{Ir} \sim \mathrm{Pt} \sim \mathrm{Rh} \sim \mathrm{Pd} \sim \mathrm{Ni} \sim \mathrm{Os} \gg \mathrm{Co} » \mathrm{Fe}$ with Tafel slopes ranging from 46 to $191 \mathrm{mV}$ dec $^{-}$ 1 .

Precious metal ( $\mathrm{Ru}, \mathrm{Ir})$ alloys with nickel have also been studied [79] but the decrease in overpotential for oxygen evolution compared to nickel is small and the use of such alloys is unlikely to warrant the additional cost. In addition, it was found that after long term electrolysis, the surface film was largely nickel oxide, independent of the bulk alloy composition. The precious metal oxides dissolved in the alkaline medium. $\mathrm{RuO}_{2}$ and $\mathrm{IrO}_{2}$ exhibit good electrocatalytic activity for oxygen evolution and are generally the electrocatalysts of choice in acid solutions but there are doubts about their stability in alkaline media as they suffer slow dissolution in alkaline solution $[28,80]$. Also, thermal treatment [81] 
or addition of $\mathrm{Ta}_{2} \mathrm{O}_{5}$ [82] have been suggested to improve their lifetime in acid solution but such modifications have not been examined in alkaline solution.

Pyrochlore-type and delafossite-type oxides containing precious metal have demonstrated outstanding activities toward oxygen evolution in alkaline solution. Pyrochloretype oxides have the general formula $\mathrm{A}_{2}\left[\mathrm{~B}_{2-\mathrm{x}} \mathrm{A}_{\mathrm{x}}\right] \mathrm{O}_{7-\mathrm{y}}$, where $\mathrm{A}=\mathrm{Pb}$ or $\mathrm{Bi}, \mathrm{B}=\mathrm{Ru}$ or Ir, $0<x<1$ and $0<y<0.5$. Horowitz and coworkers [83] report that the pyrochlore oxide $\mathrm{Pb}_{2}\left[\mathrm{Ru}_{1.67} \mathrm{~Pb}_{0.33}\right] \mathrm{O}_{6.5}$ displayed a very low overpotential for oxygen evolution in $3 \mathrm{M} \mathrm{KOH}$ at $348 \mathrm{~K}$ with better performance than $\mathrm{Pt}$ black, $\mathrm{RuO}_{2}, \mathrm{NiCo}_{2} \mathrm{O}_{4}$ and $\mathrm{Ni}$ sheet. The electrocatalyst also showed reasonable activity maintenance over long periods (500-1800 h) of oxygen evolution at current densities $0.025-0.1 \mathrm{~A} \mathrm{~cm}^{-2}$. Other promising pyrochlores include $\mathrm{Pb}_{2}\left(\mathrm{Ir}_{1.67} \mathrm{~Pb}_{0.33}\right) \mathrm{O}_{6.5}$ and $\mathrm{Nd}_{3} \mathrm{IrO}_{7}$ [84]. The pyrochlores give a low Tafel slope, $24-40$ $\mathrm{mV} \operatorname{dec}^{-1}$ and their high activity of these oxides was explained in terms of their oxygen deficiency. Delafossite-type oxides also show activity for oxygen evolution [85] decreasing in the order $\mathrm{PtCoO}_{2}>\mathrm{PdCoO}_{2}>\mathrm{PdRhO}_{2}>\mathrm{PdCrO}_{2}$.

Electrocatalysts based on nickel and/or cobalt (high area metal, oxide/hydroxide layers, spinels, perovskites) generally outperform precious metal materials in terms of both overpotential and stability as well as being lower cost. In early work, Hall [86,87] confirmed the advantage of using $\mathrm{Ni}$ metal in a high area form. The coating was fabricated by sintering a $\mathrm{Ni}$ powder (prepared by the thermal decomposition of nickel tetracarbonyl) onto a steel substrate. Anodes prepared in this way had an oxygen evolution overpotential of $250 \mathrm{mV}$ at $0.4 \mathrm{~A} \mathrm{~cm}^{-2}$ in $30 \mathrm{wt} \% \mathrm{KOH}$ at $353 \mathrm{~K}$ and a Tafel slope of $\sim 35 \mathrm{mV} \mathrm{dec}^{-1}$. They also gave a stable performance, the anode potential being essentially constant for $1200 \mathrm{~h}$ at $0.1 \mathrm{~A} \mathrm{~cm}^{-2}$. The author suggested that the anode can be stabilized by formation of a protective nickel-iron alloy layer at the steel surface, resulting from nickel diffusion into the steel during sintering. The effective surface area of nickel anode can be further increased by impregnation of the porous structure with nickel hydroxide via electrochemical precipitation methods [88]. Such procedures lowered the oxygen evolution overpotential by a further $45-60 \mathrm{mV}$ with a preferred $\mathrm{Ni}(\mathrm{OH})_{2}$ loading of $1-4 \mathrm{mg} \mathrm{cm}^{-2}$.

Another successful approach to obtaining a low overpotential involves the use of mixed transition metal oxide/hydroxides particularly iron-doped nickel hydroxide composites [89-93]. Corrigan [89] first reported that co-precipitaion of iron into nickel hydroxide thin films dramatically improved the catalysis of the oxygen evolution reaction. A substantial contribution arises from the lowering the Tafel slope from about $70 \mathrm{mV} \mathrm{dec}{ }^{-1}$ with no iron present to about $25 \mathrm{mV} \mathrm{dec}{ }^{-1}$ with $10-50 \mathrm{wt} \%$ iron. The oxygen overpotential on thin films 
of $\mathrm{NiFe}(\mathrm{OH})_{2}$ electrodes was over $200 \mathrm{mV}$ lower than that with nickel hydroxide itself at 0.08 $\mathrm{A} \mathrm{cm}^{-2}$ in $25 \mathrm{wt} \% \mathrm{KOH}$ at $296 \mathrm{~K}$. The enhanced electrocatalytic activity of iron-doped nickel hydroxide composites for oxygen evolution was later confirmed by other researchers [91-93]. Li et al. [93] compared a number of nickel based coatings, see figure 5, including a spinel and concluded that a cathodically prepared Ni-Fe hydroxide coating was the anode of choice for a zero gap alkaline water electrolyser.

It has been known for over 30 years that spinel oxides are effective anodes for oxygen evolution with promising long timescale performance [94]. Tseung et al [95-98] pioneered the use of $\mathrm{NiCo}_{2} \mathrm{O}_{4}$ and pure or Li-doped $\mathrm{Co}_{3} \mathrm{O}_{4}$. Teflon-bonded $\mathrm{NiCo}_{2} \mathrm{O}_{4}$ electrodes gave over $1.3 \mathrm{~A} \mathrm{~cm}^{-2}$ at an overpotential of $400 \mathrm{mV}$ in $5 \mathrm{M} \mathrm{KOH}$ at $343 \mathrm{~K}$ and endured long-term oxygen evolution at $1 \mathrm{~A} \mathrm{~cm}^{-2}$ at $358 \mathrm{~K}$ in $45 \mathrm{wt} \% \mathrm{KOH}$ for $3000 \mathrm{~h}$ with less than $50 \mathrm{mV}$ increase in overpotential. Similar performance was observed by Vandenborre et al. [99] who developed a zero gap alkaline water electrolyser based on an alkali-compatible ion exchange membrane. Among the tested anodes including $\mathrm{Ni}, \mathrm{NiCo}_{2} \mathrm{O}_{4}, \mathrm{NiCoO}_{2}$, and $\mathrm{La}_{\mathrm{x}} \mathrm{CoO}_{3} ; \mathrm{NiCo}_{2} \mathrm{O}_{4}$ spinel oxide showed the best performance up to $393 \mathrm{~K}$ in $50 \mathrm{wt} \% \mathrm{KOH}$ for $2000 \mathrm{~h}$ operation. The tested $\mathrm{NiCo}_{2} \mathrm{O}_{4}$ electrodes were prepared by thermal decomposition of nickel and cobalt salts on perforated nickel plates.

Tseung et al [98] also reported that $\mathrm{Li}$-doped $\mathrm{Co}_{3} \mathrm{O}_{4}$ was a superior catalyst to $\mathrm{NiCo}_{2} \mathrm{O}_{4}$ with a Teflon bonded Li-doped $\mathrm{Co}_{3} \mathrm{O}_{4}$ electrode giving $1 \mathrm{~A} \mathrm{~cm}^{-2}$ at an overpotential of $\sim 300$ $\mathrm{mV}$ in $5 \mathrm{M} \mathrm{KOH}$ at $343 \mathrm{~K}$. Moreover, long-term durability tests carried out on this electrode under practical conditions (at $1 \mathrm{~A} \mathrm{~cm}^{-2}$ in $45 \mathrm{wt} \% \mathrm{KOH}$ at $358 \mathrm{~K}$ ) showed good stability of performance for $5800 \mathrm{~h}$. In contrast, Bocca et al. [100] observed a general decay on these electrodes performance subjected to galvanostatic electrochemical ageing for 21 days at 0.15 $\mathrm{A} \mathrm{cm}^{-2}$ at $333 \mathrm{~K}$, but pointed out that parameters in the fabrication of the electrodes leading to different oxide morphology and Teflon contents could lead to this difference.

During the last three decades, considerable effort has been made to enhance the performance of spinel-type oxides for oxygen evolution by (i) the development of new preparative methods to achieve high active area and (ii) partial substitution of constituent metal ions of the oxide by other similar metal ions. The developed preparation methods include thermal decomposition [94, 98-100], freeze drying method [97], sol-gel method [101,102], vacuum evaporation [103], chemical spray pyrolysis [104], electrophoretic deposition [105], and hydroxide co-precipitation method [106] etc. Various ternary spinel oxides have been studied and shown promising activity toward oxygen evolution [107-110]. 
Perovskites are a family of oxides having a crystal structure similar to that of the mineral perovskite $\mathrm{CaTiO}_{3}$ and have a general chemical formula $\mathrm{ABO}_{3}$ [111], where $\mathrm{A}$ is a larger cation (such as $\mathrm{La}, \mathrm{Sr}$, and $\mathrm{Nd}$ ) and $\mathrm{B}$ a small transition metal cation (such as $\mathrm{Ni}, \mathrm{Co}$, $\mathrm{Fe}, \mathrm{Mn}$, etc). They are usually prepared by thermal decomposition of an appropriate mixture of metal salts or by the solid state reaction of metallic oxides and they possess high electronic conductivity which is favourable for electrochemical catalysis. Matsumoto et al [112-116] have reported investigations of several perovskite-type oxides including $\mathrm{SrFeO}_{3}$, $\mathrm{SrFe}_{0.9} \mathrm{M}_{0.1} \mathrm{O}_{3}, \mathrm{La}_{1-\mathrm{x}} \mathrm{Sr}_{\mathrm{x}} \mathrm{CoO}_{3}, \mathrm{La}_{1-\mathrm{x}} \mathrm{Sr}_{\mathrm{x}} \mathrm{CoO}_{3}$, and $\mathrm{La}_{1-\mathrm{x}} \mathrm{Sr}_{\mathrm{x}} \mathrm{Fe}_{1-\mathrm{y}} \mathrm{Co}_{\mathrm{y}} \mathrm{O}_{3}$ as anodes for oxygen evolution in alkaline solutions. The catalytic performance is reasonable but probably not as good as the spinels and the mixed transition metal oxide/hydroxides. Moreover, slow dissolution of $\mathrm{SrFeO}_{3}$ was observed in the conditions for oxygen evolution in alkali [112] although this problem may be overcome by doping other transition metals into the structure to form $\mathrm{SrFe}_{0.9} \mathrm{M}_{0.1} \mathrm{O}_{3}$, where $\mathrm{M}=\mathrm{Ni}$, Co, Ti, or $\mathrm{Mn}$. Indeed, the anodic dissolution is much suppressed by the substitution with Ni or Co ion [114]. Detailed studies on mechanism for oxygen evolution reaction on $\mathrm{La}_{1-x} \mathrm{Sr}_{x} \mathrm{Fe}_{1-y} \mathrm{Co}_{\mathrm{y}} \mathrm{O}_{3}$ series oxides show that the rate of the oxygen evolution reaction increases with the increases of $x$ and $y$, and $\mathrm{La}_{0.2} \mathrm{Sr}_{0.8} \mathrm{Fe}_{0.2} \mathrm{Co}_{0.8} \mathrm{O}_{3}$ is the best electrocatalyst of the oxides investigated [116]. Bockris and Otagawa [117-119] used voltammetric techniques with eighteen perovskites and correlated the electrocatalytic properties of perovskites for oxygen evolution with their electronic structures, with stress upon the characterization of the bonding of surface oxygenated intermediates. Using Tafel slopes and reaction orders for oxygen evolution they proposed a common mechanism involving the electrochemical adsorption of $\mathrm{OH}^{-}$, followed by the rate-determining electrochemical desorption of $\mathrm{OH}$ and catalytic disproportionation of the $\mathrm{H}_{2} \mathrm{O}_{2}$ to give $\mathrm{O}_{2}$. $\mathrm{LaNiO}_{3}$ gives the highest electrocatalytic activity among the perovskites studied and exhibits a stable performance for over $70 \mathrm{~h}$ at $0.1 \mathrm{~A} \mathrm{~cm}^{-2}$ in $1 \mathrm{M} \mathrm{NaOH}$ at $298 \mathrm{~K}$.

In more recent work, Singh and co-workers [120-125] have worked further on perovskite anodes. They synthesized the oxides by low temperature routes such as malic acid aided sol-gel method and carbonate precipitation. The oxides were active for oxygen evolution compared to similar electrodes obtained by other methods. For instance, the oxygen overpotentials observed on $\mathrm{La}_{0.8} \mathrm{Sr}_{0.2} \mathrm{CoO}_{3}$ electrode in $30 \mathrm{wt} \% \mathrm{KOH}$ at $343 \mathrm{~K}$ were 305 and $340 \mathrm{mV}$ at 0.5 and $1 \mathrm{~A} \mathrm{~cm}^{-2}$, respectively [120,121].

While usable electrocatalysts have been defined, the last word on oxygen evolving anodes has not been said. The demand for higher performance remains and new compositions 
will continue to be tested. It is also clear that the method of catalyst preparation as well as the structure of the anode tested influence both catalytic activity and the stability of the materials.

\section{Membranes Supporting Hydroxide Transport}

As noted in the discussion of figure 1, a preferred design of alkaline water electrolyser would have a hydroxide conducting membrane with a low resistance and hence permitting water electrolysis at current densities around or above $1 \mathrm{~A} \mathrm{~cm}^{-2}$ with only a small IR loss. The membrane polymer must also be stable and it would be advantageous if the cell medium was pure water rather than an alkaline electrolyte. When the electrodes are with the membrane fabricated into an MEA, the cell structure becomes closely similar to an alkaline fuel cell. Hence the literature on alkaline fuel cells becomes very relevant to the future of alkaline water electrolysis technology.

For many years, anion permeable membranes have been available commercially from companies such as Ionics [126], Tokuyama [127] and Fuma-Tek [128]. In general, however, these membranes were intended for electrodialysis and targeted towards the transport of anions other than hydroxide; they were not stable to high $\mathrm{pH}$ conditions. Advances in hydroxide permeable polymers were necessary for the development of the bipolar membranes used in the recovery of acids and bases from salt solutions [129-131]. Even these polymers were, however, only stable to hydroxide in modest conditions ( $<2 \mathrm{M} \mathrm{OH}^{-}$, below $323 \mathrm{~K}$, low current densities) and therefore unsuitable for application in water electrolysers (or fuel cells) where the target is to operate at temperatures up to $363 \mathrm{~K}$, current densities in the range $0.5-$ $2.0 \mathrm{~A} \mathrm{~cm}^{-2}$ and often requiring stability to highly alkaline conditions. Recent years have seen substantial efforts to develop membranes with the properties required for water electrolysers and fuel cells [132,133].

It is not difficult to synthesise polymers with fixed cationic groups, designing structures with stability to attack by hydroxide at a high $\mathrm{pH}$ and elevated temperatures is a problem. Why has it proven difficult to design hydroxide conducting membranes with a low resistivity? There are a number of reasons:

(i) In most media, the transport of hydroxide is a slower process than the transport of protons and in order to obtain low resistances similar to those readily obtained for proton conducting membranes, the hydroxide conducting polymers need to have a high density of fixed ionic groups. Such polymers often have poor flexibility and mechanical integrity. This leads to the need to introduce a reinforcing mesh or a neutral copolymer in order to 
improve the physical properties of a membrane and commonly such neutral polymers are not stable to strong alkali at elevated temperatures.

(ii) The most successful proton conducting membranes are based on perfluorinated polymers with sidechains containing sulfonate groups (most notably, Nafion ${ }^{\mathrm{R}}$ supplied by Dupont) and such ionic polymers have outstanding stability to all aqueous media. Such an anion conducting membrane was once marketed (Tosflex ${ }^{\mathrm{R}}$ SF17, Tosoh Corp.), but its cost was prohibitive and it was withdrawn from sale. Other ways to introducing cationic centres into perfluorinated polymers have not yet led to commercial membranes.

(iii) In addition, in almost all hydroxide conducting polymers, the fixed ionic group is a quaternary ammonium group (- $\mathrm{NR}_{2} \mathrm{H}^{+}$groups are rapidly deprotonated in strong base) and clearly these must be stable to attack by hydroxide. Hydroxide ion is a nucleophile and leads to loss of fixed ionic groups via two types of mechanism. When the polymer structure includes a hydrogen atom bonded to the carbon $\beta$ to the positively charged nitrogen, Hoffman elimination occurs leading to a vinyl group attached to the polymer and the release of tertiary amine or release of an alkene and a tertiary amine centre as the fixed group. In the absence of such hydrogen atoms, direct nucleophilic attack on the charged nitrogen centres can lead to the loss of an alkyl group as an alcohol and again the formation of a neutral fixed tertiary amine group. The Hoffman elimination is the more rapid chemistry and hence the polymer is usually of the type polymer $-\mathrm{A}-\mathrm{N}\left(\mathrm{CH}_{3}\right)_{3}{ }^{+}$ where $\mathrm{A}$ has a structure without $\beta$-hydrogen atoms and designed to minimise the rate of nucleophilic attack on the charged nitrogen centre itself.

Some hydroxide conducting polymers only show promising performance in water electrolysis cells when in contact with concentrated aqueous alkali. This is a disadvantage since the presence of alkali increases corrosion of metal components and limits the materials that can be used both within the cell and the auxiliary equipment. While it is evident that the absence of alkali contacting the membrane/electrode structure leads to a substantial increase in cell voltage, it is not clear whether the problem lies in the membrane polymers themselves or with the contact/interface between the electrodes and polymer. It would be interesting to investigate the $\mathrm{pH}$ seen by the electrode surfaces in contact with alkaline membranes since it may not be as high as the electrocatlysts desire. In acid membrane water electrolysis cells the same problem does not occur and the cells are usually water fed. Similarly, PEM fuel cells with acid membranes operate with wet gas feeds without problem. The acid polymers are, however, strongly acidic and are used as acid catalysts in organic synthesis. Also Nafion 
solution is a common constituent of electrode inks and the equivalent solutions of hydroxide conducting solutions may not yet exist. While pure water electrolysers remain the long term goal, at the present stage, high performance, zero gap alkaline electrolysers are of great interest.

The past ten years have seen a large academic effort into the development of new hydroxide conducting polymers with low resistance. This work has involved three general approaches. The first involves radiation grafting fixed ionic groups into an existing polymer sheet. The polymer sheet can be either a perfluorinated, partially fluorinated or nonfluorinated polymer. It is soaked in a precursor molecule such as vinylbenzyltrimethylammonium chloride and then exposed to $\gamma$ irradiation or an electron beam to convert the precursor into active radicals. This approach is well illustrated by the papers published by Slade and coworkers [132-138]. The second approach has been based on the synthesis of ionic polymers with chemistries different from the traditional poly(styrene/divinylbenzene) copolymers. A common selection of polymer backbone has been a poly(arylene sulfones) [139-143] or poly(arylene ether sulfones) [144,145] and the exact structure of the backbone, the nature of the cationic fixed ionic groups and the extent of crosslinking have each been varied. Also, some groups have reported totally new synthetic routes using designed monomers, eg, substituted cyclooctenes [146]. The final approach has used poly(benzimidazole) filled with aqueous $\mathrm{KOH}$ [147-150]. While all three approaches have yielded polymers stable to strong alkali and moderate conductivities, none have sufficient conductivity to allow water electrolysis cell operation at current densities $>0.1 \mathrm{~A} \mathrm{~cm}^{-2}$ with an acceptable membrane IR drop. The IR drop across the membrane is, of course, a function of the membrane thickness as well as the polymer conductivity. Thus membranes with thicknesses down to $10 \mu \mathrm{m}$ can be considered but this makes the membranes difficult to handle during the construction and/or servicing of cells.

In parallel, it is clear that a number of companies have been seeking anion membranes appropriate for alkaline fuel cells and water electrolysers, ie. stable to strong base and able to support current densities close to $1 \mathrm{~A} \mathrm{~cm}^{-2}$. While details of the membranes are sketchy, some success can be reported. The Italian Company, Acta spa [151], have reported performance data for a $\mathrm{H}_{2} / \mathrm{O}_{2}$ fuel cell employing a membrane developed in collaboration with the University of Pisa and indicate the achievement of a current density of $1 \mathrm{~A} \mathrm{~cm}^{-2}$ although with a membrane IR drop probably approaching $250 \mathrm{mV}$. The Tokuyama Corp have been developing hydroxide conducting membranes with a lower resistance both by investigating 
new polymers and producing very thin membranes [152]. Several papers [153-156] report performance in an alkaline fuel cell and operation is possible with a power density of $320 \mathrm{~mW}$ $\mathrm{cm}^{-2}$ at a current density of $0.8 \mathrm{~A} \mathrm{~cm}^{-2}$. Moreover, a hydrazine fuel cell based on these membranes achieves a power density $620 \mathrm{~mW} \mathrm{~cm} \mathrm{~cm}^{-2}$, approaching the performance of acid membrane MEA cells. Fumatech in Germany [128] also market hydroxide conducting membranes for fuel cells but we are aware of no published performance data. CellEra Inc $[157,158]$ are marketing a fuel cell stack $(1.5 \mathrm{~kW})$ with a MEA electrode configuration based on a novel hydrocarbon, hydroxide conducting membrane and non-precious metal catalysts; they claim low cost power generation at high current densities. ITM Power [159] also appear to have developed a hydroxide conducting membrane capable of supporting a high current density with a low IR drop. Using this membrane, Li and Pletcher [93] have reported a water electrolysis cell (not fully optimised) with a cell voltage of $2.10 \mathrm{~V}$ at a current density of $1 \mathrm{~A}$ $\mathrm{cm}^{-2}$, see figure 6 .

Hydrogenics market a zero gap, alkaline water electrolysis system under the tradename Hystat $^{\mathrm{TM}}$ [14] based upon work by Vandenborre and coworkers [99,160-162]. It is, however, based on an inorganic ion exchange material, poly(antimonic acid) incorporated into a polysulfone organic binder. Unlike all the membranes discussed above, the membrane transports sodium ions, not hydroxide. When employing non-precious metal electrocatalysts, $\mathrm{NiCo}_{2} \mathrm{O}_{4}$ and $\mathrm{NiCo}_{2} \mathrm{~S}_{4}$ deposited on perforated Ni plates as the electrodes, the performance is impressive. Cell operation above $373 \mathrm{~K}$ is possible while current densities as high as $1.25 \mathrm{~A}$ $\mathrm{cm}^{-2}$ can be achieved. At a current density of $0.2 \mathrm{~A} \mathrm{~cm}^{-2}$ the cell voltage is only $1.50 \mathrm{~V}$. The technology is claimed to be both cheaper and more energy efficient than SPE cell based on Nafion ${ }^{\mathrm{TM}}$ membranes. These cells certainly demonstrate the possibilities for novel alkaline water electrolysis technology.

\section{Conclusions and The Future}

We believe that the future of zero gap, alkaline water electrolysers is highly promising. The low cost, non-precious metal electrocatalysts and hydrocarbon based membranes should lead to lower cost technology compared with zero gap, acid systems. The possibilities for low cost, energy efficiency water electrolysers are excellent. The target should be a cell voltage < $2 \mathrm{~V}$ at current densities $>1 \mathrm{~A} \mathrm{~cm}^{-2}$ for cells operating below $373 \mathrm{~K}$. At the present stage, we would assess the technology as follows:

- Low overpotential, stable hydrogen evolution catalysts are available. 
- Stable oxygen evolution catalysts have also been developed but the overpotentials are much higher than desirable. In view of the very extensive research already focused on this problem, no major reduction in overpotential seems likely. Water electrolysis technology probably has to be live with this inefficiency.

- The next major improvements are likely to arise from improvements in hydroxide conducting membranes. While chemical stability has been improved, the structural changes needed to meet requirements of mechanical stability and high conductivity still seem to oppose one another. In addition, operation with a pure water environment would be highly desirable although cells with alkaline electrolyte environments may well have a role.

- Further optimisation of the design of zero gap alkaline water electrolysers is essential. This includes studies to understand and improve the interface between membrane polymer and electrocatalysts and also materials and techniques for fabricating MEA type structures.

Work is in progress to decrease the energy consumption in other ways. The obvious route is to increase the temperature substantially. For example, cells with a highly concentrated $\mathrm{KOH}$ electrolyte and operating at up to $700 \mathrm{~K}$, and at high pressure show much reduced overpotentials for oxygen evolution $[163,164]$ and significant reduction in the cell voltage. Development to commercial technology will, however, require identification of novel, stable materials. Another approach for hydrogen generation technology is to replace the oxygen evolving anode by another anode reaction. Candidates that certainly decrease the thermodynamic energy input for hydrogen generation would be the oxidation of urea or methanol; indeed, reductions in cell voltage can be achieved [165] although the current densities for the reactions would need to be increased substantially. One can also question the 'green pedigree' of this approach since environmentally unfriendly products are also produced. For example, a cell where the anode reaction is the oxidation of urea would produce 0.33 mole of carbon dioxide for each mole of hydrogen (as well as the possibility of some oxides of nitrogen as minor products).

There is also current interest in the concept of reversible $\mathrm{O}_{2} / \mathrm{H}_{2}$ fuel cells for energy storage [16]. This challenging concept envisages the generation of hydrogen and oxygen during charge (or the storage of energy) and the recombination back to water during discharge (or the release of stored energy) in a single cell. Despite an extensive literature on catalysts $[17,166]$, at present, the energy efficiency is very poor, certainly $<40 \%$. Significant 
improvements are only probable when high performance alkaline water electrolysers have been achieved.

\section{References}

[1] Tilak BV, Lu PWT, Colman JE, Srinivasan S. Electrolytic production of hydrogen. In: Bockris JO'M, Conway BE, Yeager E, White RE, editors. Comprehensive Treatise of Electrochemistry, Volume 2, Plenum; 1981, p. 1-104.

[2] Wendt H, Imarisio G. Nine years of research and development on advanced water electrolysis - A review of the research-program of the commission-of-the-Europeancommunities. J Appl Electrochem 1988; 18: 1-14.

[3] Wendt H. Electrochemical Hydrogen Technologies. Elsevier; 1990.

[4] Pletcher D, Walsh FC. Industrial Electrochemistry. Chapman and Hall; 1991.

[5] Plzak V, Rohland B, Wendt H. In: White RE, Bockris JO'M, Conway BE, editors. Modern Aspects of Electrochemistry, Volume 26, Plenum; 1994.

[6] McElroy JF. Recent advances in SPE water electrolyser. J Power Sources 1994; 47: $369-75$.

[7] La Conti AB, Swette L. Special applications using PEM-technology. In: Vielstich W, Lamm A, Gasteiger HA, editors. Handbook of Fuel Cells, Volume 3, Wiley; 2003, Part 3, p. 745-61.

[8] Grigoriev SA, Porembskii VI, Fateev VN. Pure hydrogen production by PEM electrolysis for hydrogen energy. Int J Hydrogen Energy 2006; 31: 171-5.

[9] Hamann CH, Röpke T, Schmittinger P. Electrowinning of other inorganic compounds. In: MacDonald DD, Schmuki P, editors. Encyclopedia of Electrochemistry, Volume 5, Wiley; 2007, p. 299-304.

[10] Zoulias E, Varkaraki E, Lymberopoulos N. Hydrogen-based uninterruptible power supply. Int J Hydrogen Energy 2007; 32: 1589-96.

[11] Zeng K, Zhang D. Recent progress in alkaline water electrolysis for hydrogen production and applications. Prog Energy Combust Sci 2010; 36: 307-26.

[12] Weissermel K, Arpe H-J. Industrial Organic Chemistry. Verlag Chemie; 1978, p. $24-7$.

[13] Saur G. The Wind to Hydrogen Project: Electrolyzer Capital Cost Study, Report NREL/TP-550-44103, 2008.

[14] Hydrogenics.com [Internet]. Canada: Hydrogenics Corporation Plc.; Hydrogen Generators: On Site, On Demand: HySTAT ${ }^{\mathrm{TM}}$ Electrolysers for safe and reliable 
hydrogen production; c2009-10 [updated 2009 May; cited 2011 Apr 9]. Available from: http://www.hydrogenics.com/hydro.

[15] Teledynees.com [Internet]. Maryland (USA): Teledyne Energy Systems, Inc.; TELEDYNE TITANTM Hydrogen/Oxygen Gas Generation Systems; c2009 [cited 2011 Apr 9]. Available from: http://www.teledynees.com/titan.asp.

[16] Jörissen L. Bifunctional oxygen/air electrodes. J Power Sources 2006; 155: 23-32.

[17] Pettersson J, Ramsay B, Harrison D. A review of the latest developments in electrodes for unitised regenerative polymer electrolyte fuel cells. J Power Sources 2006; 157: 2834.

[18] Modern Chlor-Alkali Technology, Volumes 1 - 8, Ellis Horwood/SCI/Wiley; 1980 2001.

[19] Vielstich W, Gasteiger HA, Lamm A, editors. Handbook of Fuel Cells, Volumes 1 - 5, Wiley; 2003.

[20] Hoogers G, editor. Fuel Cells Technology Handbook. CRC Press; 2003.

[21] Harrison KW, Martin GD, Ramsden TG, Kramer WE, Novachek FJ. The Wind to Hydrogen Project: Operational Experience, Performance Testing and Systems Integration, Report NREL/TP-550-44082, 2009.

[22] Pletcher D. A First Course in Electrode Processes. Royal Society of Chemistry; 2009.

[23] Appleby AJ, Kita H, Chemla M, Bronoel G. Hydrogen. In: Bard AJ, editor. Encyclopedia of Electrochemistry of the Elements, Volume IXa, Marcel Dekker; 1982, p. 383-597.

[24] Trasatti S. Progress in cathode activation. In: Gerischer H, Tobias CW, editors. Advances in Electrochemical Science and Engineering, Volume 2, VCH; 1992, p. 1-85.

[25] Breiter MW. The hydrogen oxidation/evolution reaction. In: Vielstich W, Gasteiger HA, Lamm A, editors. Handbook of Fuel Cells, Volume 2, Wiley; 2003, p. 361-80.

[26] Couper AM, Pletcher D, Walsh FC. Electrode materials for electrosynthesis. Chem Rev 1990; 90: 837-65.

[27] Hoare JP. In: Bard AJ, editor. Encyclopedia of Electrochemistry of the Elements, Volume II, Marcel Dekker; 1974, p. 192-9.

[28] Kinoshita K. Electrochemical Oxygen Technology. Wiley; 1992.

[29] L'Her M. Redox Properties, Electrochemistry of Oxygen. In: Schultz F, Pickett CJ, editors. Encyclopedia of Electrochemistry, Volume 7a. Wiley; 2006, p. 117-42. 
[30] Nidola A, Schira R. Poisoning mechanisms and structural-analyses on metallic contaminated cathode catalysts in chloralkali membrane cell technology. J Electrochem Soc 1986; 133: 1653-6.

[31] O'Brian TF, Tilak BV, Hine F. Handbook of Chlor-Alkali Technology, Volume 1. Springer; 2005, p. 241-71.

[32] Bockris JO'M, Subramanyan PK. The equivalent pressure of molecular hydrogen in cavities within metals in terms of the overpotential developed during the evolution of hydrogen. Electrochim Acta 1971; 16: 2169-79.

[33] Miles MH, Kissel G, Lu PWT, Srinivasan S. Effect of temperature on electrode kineticparameters for hydrogen and oxygen evolution reactions on nickel electrodes in alkaline solutions. J Electrochem Soc 1976; 123: 332-6.

[34] Appleby AJ, Crepy G, Jacquelin J. High-efficiency water electrolysis in alkaline solution. Int J Hydrogen Energy 1978; 3: 21-37.

[35] Ferreira AC, Gonzalez ER, Ticianelli EA, Avaca AA, Matvienko B. The effect of temperature on the water electrolysis reactions on nickel and nickel-based codeposits. J Appl Electrochem 1988; 18: 894-8.

[36] Cairns JF, Couper AM, Denton DA. Electrode coatings for membrane cells. In: Wall K, editor. Modern Chlor-Alkali Technology, Volume 3. SCI/Horwood; 1986, p. 293-309.

[37] Groves DE. Precious-metal activated cathodes for chlor-alkali cells. In: Wall K, editor. Modern Chlor-Alkali Technology, Volume 3. SCI/Horwood; 1986, p. 250-62.

[38] Cameron DS, Phillips RL, Willis PM. Poison tolerant platinum catalysed cathodes for membrane cells. In: Prout NM, Moorhouse JS, editors. Modern Chlor-Alkali Technology, Volume 4. SCI/Elsevier Applied Science; 1990, p. 95-107.

[39] Cairns JF, Cook MR, Hayes PM, Hodgson DR, Izzard PA, Mockford MJ, et al. Advances in ICI's activated cathode technology for chlor-alkali production. Proc Electrochem Soc 1998; 98: 289-96.

[40] Trasatti S. Hydrogen evolution on oxide electrodes. In: Wellington TC, editor. Modern Chlor-Alkali Technology, Volume 5. SCI/Elsevier Applied Science; 1992, p. 281-94.

[41] Trasatti S. Interfacial electrochemistry of conductive oxides for electrolysis. In: Wieckowski A, editor. Interfacial Electrochemistry - Theory, Experiment and Applications. Marcel Dekker; 1999, p. 769-92.

[42] Danna PA, Woodard KE. Olin membrane cell technology. In: Jackson C, editor. Modern Chlor-Alkali Technology, Volume 2. SCI/Horwood; 1983, p. 121-31. 
[43] Dworak R, Lohrberg K, Müller R. Lurgi's experience with steel and Raney-nickel as cathode material. In: Wellington TC, editor. Modern Chlor-Alkali Technology, Volume 5. SCI/Elsevier Applied Science; 1992, p. 257-64.

[44] Brown DE, Fogarty PO, Mahmood MN, Turner AK. The development of low overvoltage cathodes. In: Jackson C, editor. Modern Chlor-Alkali Technology, Volume 2. SCI/Horwood; 1983, p. 233-45.

[45] Brown DE, Mahmood MN, Man MCM, Turner AK. Preparation and characterisation of low overvoltage transition-metal alloy electrocatalysts for hydrogen evolution in alkaline solutions. Electrochim Acta 1984; 29: 1551-6.

[46] Bianchi I, Guerrini E, Trasatti S. Electrocatalytic activation of $\mathrm{Ni}$ for $\mathrm{H}_{2}$ evolution by spontaneous deposition of Ru. Chem Phys 2005; 319: 192-9.

[47] Vázquez-Gómez L, Cattarin S, Guerriero P, Musiani M. Hydrogen evolution on porous $\mathrm{Ni}$ cathodes modified by spontaneous deposition of Ru or Ir. Electrochim Acta 2008; 53: 8310-8.

[48] Antozzi AL, Bargioni C, Iacopetti L, Musiani M, Vázquez-Gómez L. EIS study of the service life of activated cathodes for the hydrogen evolution reaction in the chlor-alkali membrane cell process. Electrochim Acta 2008; 53: 7410-6.

[49] Kinoshita K. Carbon Electrochemical and Physicochemical Properties. Wiley; 1988.

[50] Porbaix M. Atlas of Electrochemical Equilibria in Aqueous Solutions. Pergamon Press; 1966.

[51] Burke LD, Naser NS. Metastability and electrocatalytic activity of ruthenium dioxide cathodes used in water electrolysis cells. J Appl Electrochem 2005; 35: 931-8.

[52] Spãtaru N, Le Helloco J-G, Durand R. A study of $\mathrm{RuO}_{2}$ as an electrocatalyst for hydrogen evolution in alkaline solution. J Appl Electrochem 1996; 26: 397-402.

[53] Beer HB. The invention and industrial-development of metal anodes. J Electrochem Soc 1980; 127: C303-7.

[54] Iwakura C, Furukawa N, Tanaka M. Electrochemical preparation and characterisation of $\mathrm{Ni} /\left(\mathrm{Ni}+\mathrm{RuO}_{2}\right)$ composite coatings as an active cathode for hydrogen evolution. Electrochim Acta 1992; 37: 757-8.

[55] Iwakura C, Tanaka M, Nakamatsu S, Inoue H, Matsuoka M, Furukawa N. Electrochemical properties of $\mathrm{Ni} /\left(\mathrm{Ni}+\mathrm{RuO}_{2}\right)$ active cathodes for hydrogen evolution in chloralkali electrolysis. Electrochim Acta 1995; 40: 977-82.

[56] Tavares AC, Trasatti S. Ni+RuO 2 co-deposited electrodes for hydrogen evolution. Electrochim Acta 2000; 45: 4195-202. 
[57] Vázquez-Gómez L, Cattarin S, Guerriero P, Musiani M. Preparation and electrochemical characterization of $\mathrm{Ni}+\mathrm{RuO}_{2}$ composite cathodes of large effective area. Electrochim Acta 2007; 52: 8055-63.

[58] Vázquez-Gómez L, Cattarin S, Guerriero P, Musiani M. Influence of deposition current density on the composition and properties of electrodeposited $\mathrm{Ni}+\mathrm{RuO}_{2}$ and $\mathrm{Ni}+\mathrm{IrO}_{2}$ composites. J Electroanal Chem 2009; 634: 42-8.

[59] Tsou YM. Reinforced composite-reductively deposited catalytic coating for hydrogen evolution. J Electroanal Chem 2001; 498: 223-7.

[60] Endoh E, Otouma H, Morimoto T, Oda Y. New Raney-nickel composite-coated electrode for hydrogen evolution. Int J Hydrogen Energy 1987; 12: 473-9.

[61] Divisek J, Schmidt H, Mergel J. Novel diaphragms and electrode designs for electrolysis of water and alkali chloride. Chem Ing Tech 1980; 52: 465.

[62] Rausch S, Wendt H. Morphology and utilization of smooth hydrogen-evolving raney nickel cathode coatings and porous sintered-nickel cathodes. J Electrochem Soc 1996; 143: $2852-62$.

[63] Tanaka S, Hirose N, Tanaki T, Ogatab YH. Effect of Ni-Al precursor alloy on the catalytic activity for a Raney-Ni cathode. J. Electrochem Soc 2000; 147: 2242-5.

[64] Yoshida N, Morimoto T. A new low hydrogen overvoltage cathode for chloralkali electrolysis cell. Electrochim Acta 1994; 39: 1733-7.

[65] Shervedani RK, Lasia A. Study of the hydrogen evolution reaction on Ni-Mo-P electrodes in alkaline solutions. J Electrochem Soc 1998; 145: 2219-25.

[66] Han Q, Cui S, Pu N, Chen J, Liu K, Wei X. A study on pulse plating amorphous Ni-Mo alloy coating used as HER cathode in alkaline medium. Int J Hydrogen Energy 2010; 35: 5194-201.

[67] Divisek J, Schmitz H, Balej J. Ni and Mo coatings as hydrogen cathodes. J Appl Electrochem 1989; 19: 519-30.

[68] Huot JY, Trudeau ML, Schulz R. Low hydrogen overpotential nanocrystalline Ni-Mo cathodes for alkaline water electrolysis. J Electrochem Soc 1991; 138: 1316-21.

[69] Rodríguez-Valdez LM, Estrada-Guel I, Almeraya-Calderón F, Neri-Flores MA, Martínez-Villafańne A, Martínez-Sánchez R. Electrochemical performance of hydrogen evolution reaction of $\mathrm{Ni}-\mathrm{Mo}$ electrodes obtained by mechanical alloying. Int J Hydrogen Energy 2004; 29: 1141-5.

[70] Miousse D, Lasia A, Borck V. Hydrogen evolution on Ni-Al-Mo and Ni-Al electrodes prepared by low-pressure plasma spraying. J Appl Electrochem 1995; 25: 592-602. 
[71] Schiller G, Henne R, Mohr P, Peinecke P. High performance electrodes for an advanced intermittently operated 10-kW alkaline water electrolyzer. Int J Hydrogen Energy 1998; 23: 761-5.

[72] Birry L, Lasia A. Studies of the hydrogen evolution reaction on Raney nickelmolybdenum electrodes. J Appl Electrochem 2004; 34: 735-49.

[73] Hu W, Cao X, Wang F, Zhang Y. A novel cathode for alkaline water electrolysis. Int J Hydrogen Energy 1997; 22: 441-3.

[74] $\mathrm{Hu} \mathrm{W}$. Electrocatalytic properties of new electrocatalysts for hydrogen evolution in alkaline water electrolysis. Int J Hydrogen Energy 2000; 25: 111-8.

[75] Li X, Pletcher D. unpublished work.

[76] Hall DE. Alkaline water electrolysis anode materials. J Electrochem Soc 1985; 132: C41-8.

[77] Miles MH. Evaluation of electrocatalysts for water electrolysis in alkaline solutions. J Electroanal Chem 1975; 60: 89-96.

[78] Miles MH, Huang YH, Srinivasan S. The oxygen electrode reaction in alkaline solutions on oxide electrodes prepared by the thermal decomposition method. $\mathrm{J}$ Electrochem Soc 1978; 125: 1931-4.

[79] Lu PWT, Srinivasan S. Nickel-based alloys as electrocatalysts for oxygen evolution from alkaline solutions. J Electrochem Soc 1978; 125: 265-70.

[80] Rasiyah P, Tseung ACC. The role of the lower metal oxide/higher metal oxide couple in oxygen evolution reactions. J Electrochem Soc 1984; 131: 803-8.

[81] Vukovic M. Oxygen evolution reaction on thermally treated iridium oxide films. J Appl Electrochem 1987; 17: 737-45.

[82] Rolewicz J, Comninellis C, Plattner E, Hinden J. Characterization of oxygen evolving DSA electrodes. 1. $\mathrm{Ti} / \mathrm{IrO}_{2}-\mathrm{Ta}_{2} \mathrm{O}_{5}$ electrodes. Electrochim Acta 1988; 33: 573-80.

[83] Horowitz HS, Longo JM, Horowitz HH. Oxygen electrocatalysis on some oxide pyrochlores. J Electrochem Soc 1983; 130: 1851-9.

[84] ten Kortenaar MV, Vente JF, Ijdo DJW, Müller S, Kötz R. Oxygen evolution and reduction on iridium oxide compounds. J Power Sources 1995; 56: 51-60.

[85] Carcia PF, Shannon RD, Bierstedt PE, Flippen RB. Electrocatalysis on thin film metallic oxide electrodes with the delafossite structure. J Electrochem Soc 1980; 127: 1974-8.

[86] Hall DE. Electrodes for alkaline water electrolysis. J Electrochem Soc 1981; 128: 740-6. 
[87] Hall DE. Porous nickel-coated steel anodes for alkaline water electrolysis: Corrosion Resistance. J Electrochem Soc 1982; 129: 310-5.

[88] Hall DE. $\mathrm{Ni}(\mathrm{OH})_{2}$-impregnated anodes for alkaline water electrolysis. J Electrochem Soc 1983; 130: 317-21.

[89] Corrigan DA. The catalysis of the oxygen evolution reaction by iron impuries in thin film nickel oxide electrodes. J Electrochem Soc 1987; 134: 377-84.

[90] Miller EL, Rocheleau RE. Electrochemical behaviour of reactively sputtered irondoped nickel oxide. J Electrochem Soc 1997; 144: 3072-7.

[91] Merrill MD, Dougherty RC. Metal oxide catalysts for the evolution of $\mathrm{O}_{2}$ from $\mathrm{H}_{2} \mathrm{O}$. J Phys Chem C 2008; 112: 3655-66.

[92] Kleiman-Shwarsctein A, Hu Y, Stuckey GD, McFarland EW. NiFe-oxide electrocatalysts for the oxygen evolution reaction on Ti doped hematite photoelectrodes. Electrochem Commun 2009; 11: 1150-3.

[93] Li X, Walsh FC, Pletcher D. Nickel based electrocatalysts for oxygen evolution in high current density alkaline water electrolysers. Phys Chem Chem Phys 2011; 13: 1162-7.

[94] Tarasevich MR, Efremov BN. Properties of spinel-type oxide electrodes. In: Trasatti S, editor. Electrodes of conductive metallic oxides. Elsevier Scientific Publishing Company; 1980, p. 221-59.

[95] Tseung ACC, Jasem SM. Oxygen evolution on semiconducting oxides. Electrochim Acta $1977 ; 22: 31-4$

[96] Jasem SM, Tseung ACC. A potentiostatic pulse study of oxygen evolution on Teflonbonded nickel-cobalt oxide electrodes. J Electrochem Soc 1979; 126: 1353-60.

[97] Rasiyah P, Tseung ACC. A mechanistic study of oxygen evolution on $\mathrm{NiCo}_{2} \mathrm{O}_{4} . \mathrm{J}$ Electrochem Soc 1983; 130:2384-6.

[98] Rasiyah P, Tseung ACC. A mechanistic study of oxygen evolution on Li-doped $\mathrm{Co}_{3} \mathrm{O}_{4}$. J Electrochem Soc 1983; 130: 365-8.

[99] Vandenborre H, Leysen R, Nacydrogen H. Developments on IME-alkaline water electrolysis. Int J Hydrogen Energy 1983; 8: 81-3.

[100] Bocca C, Cerisola G, Magnone E, Barbucci A. Oxygen evolution on $\mathrm{Co}_{2} \mathrm{O}_{3}$ and Lidoped $\mathrm{Co}_{2} \mathrm{O}_{3}$ coated electrodes in an alkaline solution. Int J Hydrogen Energy 1999; 24: 699-707.

[101] Singh RN, Pandey JP, Singh NK, Lal B, Chartier P, Koenig JF. Sol-gel derived spinel $\mathrm{M}_{\mathrm{x}} \mathrm{Co}_{3-\mathrm{x}} \mathrm{O}_{4}(\mathrm{M}=\mathrm{Ni}, \mathrm{Cu} ; 0<\mathrm{x}<1)$ films and oxygen evolution. Electrochim Acta 2000; 45: 1911-9. 
[102] Švegl F, Orel B, Grabec-Švegl I, Kaučič V. Characterization of spinel $\mathrm{Co}_{3} \mathrm{O}_{4}$ and Lidoped $\mathrm{Co}_{3} \mathrm{O}_{4}$ thin film electrocatalysts prepared by the sol-gel route. Electrochim Acta 2000; 45: 4359-71.

[103] Rashkova V, Kitova S, Konstantinov I, Vitanov T. Vacuum evaporated thin films of mixed cobalt and nickel oxides as electrocatalyst for oxygen evolution and reduction. Electrochim Acta 2002; 47: 1555-60.

[104] Hamdani M, Pereira MIS, Douch J, Ait Addi A, Berghoute Y, Mendonça MH. Physicochemical and electrocatalytic properties of $\mathrm{Li}^{-} \mathrm{Co}_{3} \mathrm{O}_{4}$ anodes prepared by chemical spray pyrolysis for application in alkaline water electrolysis. Electrochim Acta 2004; 49: 1555-63.

[105] Yang J, Li J, Lin H, Yang X, Tong X, Guo G. A novel preparation method for $\mathrm{NiCo}_{2} \mathrm{O}_{4}$ electrodes stacked with hexagonal nanosheets for water electrolysis. J Appl Electrochem 2006; 36: 945-50.

[106] Chi B, Lin H, Li J. Cations distribution of $\mathrm{Cu}_{\mathrm{x}} \mathrm{Co}_{3-\mathrm{x}} \mathrm{O}_{4}$ and its electrocatalytic activities for oxygen evolution reaction. Int J Hydrogen Energy 2008; 33: 4763-8.

[107] Lee Y, Hu C, Wen T. Oxygen evolution on Co-Cu-Zn ternary spinel oxide-coated electrodes in alkaline solution. J Electrochem Soc 1996; 143: 1218-25.

[108] Wen T, Kang H. Co-Ni-Cu ternary spinel oxide-coated electrodes for oxygen evolution in alkaline solution. Electrochim Acta 1998; 43: 1729-45.

[109] Nikdov I, Darkaoui R, Zhecheva E, Stoyanova R, Dimitrov N, Vitanov T. Electrocatalytic activity of spine1 related cobaltites $\mathrm{M}_{\mathrm{x}} \mathrm{Co}_{3-\mathrm{x}} \mathrm{O}_{4}(\mathrm{M}=\mathrm{Li}, \mathrm{Ni}, \mathrm{Cu})$ in the oxygen evolution reaction. J Electroanal Chem 1997; 429: 157-68.

[110] Singh RN, Singh JP, Lal B, Thomas MJK, Bera S. New $\mathrm{NiFe}_{2-\mathrm{x}} \mathrm{Cr}_{\mathrm{x}} \mathrm{O}_{4}$ spinel films for $\mathrm{O}_{2}$ evoluiton in alkaline solutions. Electrochim Acta 2006; 51: 5515-23.

[111] Tamura H, Yoneyama H, Matsumoto Y. Physicochemical and electrochemical properties of perovskite oxides. In: Trasatti S, editor. Electrodes of conductive metallic oxides. Elsevier Scientific Publishing Company; 1980, p. 261-99.

[112] Matsumoto Y, Kurimoto J, Sato E. Oxygen evolution on $\mathrm{SrFeO}_{3}$ electrode. J Electroanal Chem 1979; 102: 77-83.

[113] Matsumoto $\mathrm{Y}$, Sato E. Oxygen evolution on $\mathrm{La}_{1-\mathrm{x}} \mathrm{Sr}_{\mathrm{x}} \mathrm{MnO}_{3}$ electrodes in alkaline solutions. Electrochim Acta 1979; 24: 421-3.

[114] Matsumoto Y, Kurimoto J, Sato E. Anodic characteristics of $\mathrm{SrFe}_{0.9} \mathrm{M}_{0.1} \mathrm{O}_{3}$ (M: Ni, Co, Ti, Mn) electrodes. Electrochim Acta 1980; 25: 539-43. 
[115] Matsumoto Y, Manabe H, Sato E. Oxygen evolution on $\mathrm{La}_{1-\mathrm{x}} \mathrm{Sr}_{\mathrm{x}} \mathrm{CoO}_{3}$ electrodes in alkaline solutions. J Electrochem Soc 1980; 127: 811-4.

[116] Matsumoto Y, Yamada S, Nishida T, Sato E. Oxygen evolution on $\mathrm{La}_{1-\mathrm{x}} \mathrm{Sr}_{\mathrm{x}} \mathrm{Fe}_{1-\mathrm{y}} \mathrm{Co}_{\mathrm{y}} \mathrm{O}_{3}$ series oxides. J Electrochem Soc 1980; 127: 2360-4.

[117] Bockris JO’M, Otagawa T. Mechanism of oxygen evolution on perovskites. J Phys Chem 1983; 87: 2960-71.

[118] Bockris JO’M, Otagawa T. The electrocatalysis of oxygen evolution on perovskites. J Electrochem Soc 1984; 131: 290-302.

[119] Otagawa T, Bockris JO’M. Lanthanum nickelates as electrocatalyst: Oxygen evolution. J Electrochem Soc 1982; 129: 2391-2.

[120] Tiwari SK, Chartier P, Singh RN. Preparation of perovskite-type oxides of cobalt by the malic acid aided process and their electrocatalytic surface properties in relation to oxygen evolution. J Electrochem Soc 1995; 142: 148-53.

[121] Tiwari SK, Singh SP, Singh RN. Effect of Ni, Fe, Cu, and Cr substitutions for Co in $\mathrm{La}_{0.8} \mathrm{Sr}_{0.2} \mathrm{CoO}_{3}$ on electrocatalytic properties for oxygen evolution. $\mathrm{J}$ Electrochem Soc 1996; 143: 1505-10.

[122] Singh RN, Tiwari SK, Singh SP, Jain AN, Singh NK. Electrocatalytic activity of high specific surface area perovskite-type $\mathrm{LaNiO}_{3}$ via sol-gel route for electrolytic oxygen evolution in alkaline solution. Int J Hydrogen Energy 1997; 22: 557-62.

[123] Tiwari SK, Koenig JF, Poillerat G, Chartier P, Singh RN. Electrocatalysis of oxygen evolution/reduction on $\mathrm{LaNiO}_{3}$ prepared by a novel malic acid-aided method. $\mathbf{J}$ Appl Electrochem 1998; 28: 114-9.

[124] Singh RN, Lal B. High surface area lanthanum cobaltate and its A and B sites substituted derivatives for electrocatalysis of $\mathrm{O}_{2}$ evolution in alkaline solution. Int $\mathrm{J}$ Hydrogen Energy 2002; 27: 45-55.

[125] Lal B, Raghunandan MK, Gupta M, Singh RN. Electrocatalytic properties of perovskite-type $\mathrm{La}_{1-x} \mathrm{Sr}_{x} \mathrm{CoO}_{3}(0 \leq x \leq 0.4)$ obtained by a novel stearic acid sol-gel method for electrocatalysis of $\mathrm{O}_{2}$ evolution in $\mathrm{KOH}$ solutions. Int J Hydrogen Energy 2005; 30: 723-9.

[126] Ionicsmembranes.com [Internet]. Cambridge (UK): Ionic membranes; [cited 2011 May 10]. Available from: http://www.ionicsmembranes.com/membranes. 
[127] ASTOM-corp.jp [Internet]. Tokyo (Japan): ASTOM Corporation: Ion Exchange Membrane; c2004 [updated 2008 Jul 10; cited 2011 May 10]. Available from: http://www.astom-corp.jp/en/en-main2.html.

[128] Fumatech.com [Internet]. St. Ingbert (Germany): FuMA-Tech GmbH; c2001 [cited 2011 May 10]. Available from: http://www.fumatech.com/EN.

[129] Davis TA, Genders JD, Pletcher D. Ion Permeable Membranes. The Electrochemical Consultancy; 1997.

[130] Kemperman AJB, editor. Handbook on Bipolar Membrane Technology. Twente University Press; 2000.

[131] Strathmann H. Ion Exchange Membrane Separation Processes. Elsevier; 2004.

[132] Varcoe JR, Slade RCT. Prospects for alkaline anion-exchange membranes in low temperature fuel cells. Fuel Cells. 2005; 5: 187-200.

[133] Varcoe JR, Poynton SD, Slade RCT. Alkaline anion-exchange membranes for lowtemperature fuel cell application. In: Vielstich W, Yokokawa H, Gasteiger HA, editors. Handbook of Fuel Cells - Fundamentals, Technology and Applications. John Wiley; 2009, p. 322-33.

[134] Varcoe JR, Slade RCT, Yee ELH. An alkaline polymer electrochemical interface: a breakthrough in application of alkaline anion-exchange membranes in fuel cells. Chem Commum 2006; 1428-9.

[135] Varcoe JR, Slade RCT. An electron-beam-grafted ETFE alkaline anion-exchange membrane in metal-cation-free solid-state alkaline fuel cells. Electrochem Commun 2006; 8: 839-43.

[136] Varcoe JR, Slade RCT, Yee ELH, Poynton SD, Driscoll DJ. Investigations into the ex situ methanol, ethanol and ethylene glycol permeabilities of alkaline polymer electrolyte membranes. J Power Sources 2007; 173: 194-9.

[137] Varcoe JR, Slade RCT, Yee ELH, Poynton SD, Driscoll DJ, Appleby DC. Poly(ethylene-co-tetrafluoroethylene)-Derived Radiation-Grafted Anion-Exchange Membrane with Properties Specifically Tailored for Application in Metal-Cation-Free Alkaline Polymer Electrolyte Fuel Cells. Chem Mater 2007; 19: 2686-93.

[138] Poynton SD, Kizewski JP, Slade RCT, Varcoe JR. Novel electrolyte membranes and non-Pt catalysts for low temperature fuel cells. Solid State Ionics 2010; 181: 219-22.

[139] Park JS, Park SH, Yim SD, Yoon YG, Lee WY, Kim CS. Performance of solid alkaline fuel cells employing anion-exchange membranes. J Power Sources 2008; 178: 620-26. 
[140] Lu S, Pan J, Huang A, Zhuang L, Lu J. Alkaline polymer electrolyte fuel cells completely free from noble metal catalysts. Proc Natl Acad Sci USA 2008; 105: 206114.

[141] Wang G, Weng YM, Chu D, Chen RR, Xie D. Developing a polysulfone-based alkaline anion exchange membrane for improved ionic conductivity. J Membrane Sci 2009; 332: 63-8.

[142] Pan J, Lu S, Li Y, Huang A, Zhuang L, Lu J. High-Performance Alkaline Polymer Electrolyte for Fuel Cell Applications. Adv Functional Mater 2010; 20: 312-9.

[143] Yan J, Hickner MA. Anion exchange membranes by bromination of benzylmethylcontaining poly(sulfone)s. Macromolecules 2010; 43: 2349-56.

[144] Li L, Wang Y. Quaternized polyethersulfone Cardo anion exchange membranes for direct methanol alkaline fuel cells. J Membrane Sci 2005; 262: 1-4.

[145] Wang J, Zhao Z, Gong FX, Li SH, Zhang SB. Synthesis of soluble poly(arylene ether sulfone) ionomers with pendant quarternary ammonium groups for anion exchange membranes. Macromolecules 2009; 42: 8711-7.

[146] Robertson NJ, Kostalik HA, Clark TJ, Mutolo PF, Abruňa HD. Tunable high performance cross-linked alkaline anion exchange membranes for fuel cell applications. J Am Chem Soc 2010; 132: 3400-4.

[147] Hou H, Sun G, He R, Wu Z, Sun B. Alkali doped polybenzimidazole membrane for high performance alkaline direct ethanol fuel cell. J Power Sources 2008; 182: 95-9.

[148] Modestov AD, Tarasevich MR, Leykin AY, Filimonov VY. MEA for alkaline direct ethanol fuel cell with alkali doped PBI membrane and non-platinum electrodes. J Power Sources 2009; 188: 502-6.

[149] Xing B, Savadogo O. Hydrogenroxygen polymer electrolyte membrane fuel cells (PEMFCs) based on alkaline-doped polybenzimidazole (PBI). Electrochem Commun 2000; 2: 697-702.

[150] Savadogo O. Emerging membranes for electrochemical systems: Part II. High temperature composite membranes for polymer electrolyte fuel cell (PEFC) pplications. J Power Sources 2004; 127: 135-61.

[151] Piana M, Boccia M, Filpi Flammia A E, Miller HA, Orsini M, Santiccioli F, Ciardelli F, Pucci A. $\mathrm{H}_{2}$ /air alkaline membrane fuel cell performance and durability, using novel ionomer and non-platinum group metal cathode catalyst. J Power Sources 2010; 195 : 5875-81. 
[152] Yanagi H, Fukuta K. Anion exchange membrane and ionomer for alkaline membrane fuel cells (AMFCs). ECS Trans 2008; 16: 257-62.

[153] Matsui Y, Sato M, Tasaka A, Inaba M. Influence of carbon dioxide on the performance of anion-exchange membrane fuel cells. ECS Trans 2010; 25: 105-10.

[154] Yanagi H, Watanabe S, Sadasue K, Isomura T, Inoue H, Fukuta K. Improved performance of alkaline membrane fuel cell (AMFCs) based on newly developed electrolyte materials. Electrochem Soc Conference. Vienna; 2009; Abstract 341.

[155] Fukuta K, Inoue H, Chikashige Y, Yanagi H. Improved maximum power density of alkaline membrane fuel cells (AMFCs) by the optimization of catalyst layer construction. Electrochem Soc Conference. Vancouver; 2010; Abstract 0275.

[156] Asazawa K, Sakamoto T, Yamaguchi S, Yamada K, Fujikawa H, Tanaka H, Oguro K. Study of Anode Catalysts and Fuel Concentration on Direct Hydrazine Alkaline AnionExchange Membrane Fuel Cells. J Electrochem Soc 2009; 156: B509-12.

[157] Gottesfeld S. What really determines the rate of the ORR at metal catalysts in acid and alkaline solutions and how is the answer tied to B.E. Conway's contributions.

Electrochem Soc Conference. Vienna; 2009; Abstract 3014.

[158] CellEra-Inc.com [Internet]. Israel: CellEra Inc.; c2007 [updated 2010; cited 2011 May 10]. Available from: www.cellera-inc.com/technology.

[159] ITM-Power.com [Internet]. Sheffield (UK): ITM Power Plc. For Energy Storage and Clean Fuel Production; c2004 [cited 2011 May 10]. Available from: $\underline{w w w . i t m-}$ power.com.

[160] Vandenborre H, Leysen R. On inorganic-membrane-electrolyte water electrolysis. Electrochim Acta 1978; 23: 803-4.

[161] Vandenborre H, Leysen R, Nackaerts H, Van Asbroeck P. A survey of five year intensive R\&D work in Belgium on advanced alkaline water electrolysis. Int $\mathbf{J}$ Hydrogen Energy 1984; 9: 277-84.

[162] Vandenborre H, Leysen R, Nackaerts H, Van der Eeckens D, Van Asbroeck P, Swets W, Piepers J. Advanced alkaline water electrolysis using inorganic membrane electrolyte (I.M.E.) technology. Int J Hydrogen Energy 1985; 11: 719-26.

[163] Ganley JC. High temperature and pressure alkaline electrolysis. Int J Hydrogen Energy 2009; 34: 3604-11.

[164] Hauch A, Ebbesen SD, Jensen SH, Mogensen M. Highly efficient high temperature electrolysis. J Mater Chem 2008; 18: 2331-40. 
[165] Boggs BK, King RL, Botte G. Urea electrolysis: direct hydrogen production from urine. Chem Commun 2009; 4859-61.

[166] Nikolova V, Iliev P, Petrov K, Vitanov T, Zhecheva E, Stoyanova R, Valov I, Stoychev D. Electrocatalysts for bifunctional oxygen/air electrodes. J Power Sources 2008; 185: 727-33. 
Table 1 Comparison of the scales of operation required for some proposed applications of water electrolysis and some present technologies. Reasonable values for current density, car usage etc have been assumed. Note: the electric power generating capabilities are in the UK $5 \times 10^{4} \mathrm{MW}$, USA $8 \times 10^{5} \mathrm{MW}$ and the world $3 \times 10^{6}$ MW.

\begin{tabular}{|c|c|c|c|c|}
\hline & Power/MW & $\begin{array}{l}\mathrm{H}_{2} \text { equivalent } \\
\quad / \mathrm{kg} \mathrm{day}^{-1}\end{array}$ & $\begin{array}{l}\text { Current/A } \\
\text { monopolar }\end{array}$ & $\begin{array}{l}\text { Electrode } \\
\text { area } / \mathrm{m}^{2}\end{array}$ \\
\hline $\begin{array}{l}\text { Store electricity from a } \\
\text { typical utility power plant }\end{array}$ & 1000 & $5 \times 10^{5}$ & $5 \times 10^{8}$ & $10^{5}$ \\
\hline $\begin{array}{l}\text { Store electricity from a } \\
\text { typical wind farm } \\
\mathrm{H}_{2} \text { production facility for } \\
2000 \text { cars/day }\end{array}$ & $---\frac{-}{2}$ & $\begin{array}{c}2.5 \times 10^{4} \\
10^{3}\end{array}$ & $\begin{array}{c}2.5 \times 10^{7} \\
----- \\
10^{6}\end{array}$ & $\begin{array}{c}5 \times 10^{3} \\
------ \\
200\end{array}$ \\
\hline $\begin{array}{l}\text { Local Storage for hotel or } \\
\text { office block or group houses }\end{array}$ & 0.2 & 100 & $10^{5}$ & 20 \\
\hline $\begin{array}{l}\text { Device to fuel a single car } \\
\text { Typical } \mathrm{Cl}_{2} / \mathrm{NaOH} \text { plant }\end{array}$ & $\begin{array}{c}0.02 \\
-\boldsymbol{-}-\boldsymbol{-} \\
100\end{array}$ & $2 \times 10^{4}$ & $\begin{array}{c}10^{3} \\
2 \times 10^{7}\end{array}$ & $\begin{array}{c}0.2 \\
6 \times 10^{3}\end{array}$ \\
\hline Large $\mathrm{H}_{2} \mathrm{O}$ electrolysis plant & 6 & $3 \times 10^{3}$ & $3 \times 10^{6}$ & 600 \\
\hline
\end{tabular}




\section{Legends to Figures}

\section{Figure 1}

Sketch of an alkaline water electrolyser based on a SPE (solid polymer electrolyte) cell with a hydroxide conducting membrane.

\section{Figure 2}

Tafel plots for (a) Ni mesh (b,c) Pt-based cathodes prepared by thermal decomposition of $\mathrm{Pt}$ salts (d) $\mathrm{Ni} / \mathrm{RuO}_{2}$ nanoparticle composite in $10.4 \mathrm{M} \mathrm{NaOH}$ aqueous solution at $363 \mathrm{~K}$. Data taken from [48]. Reproduced by permission of Elsevier.

\section{Figure 3}

Scanning electron microscope images of the NiMo electrocatalyst layers produced by (a) spraying the Ni substrate with aqueous $\mathrm{Ni}(\mathrm{II})$ and molybdate solution, thermal decomposition and hydrogen reduction [67] (b) low pressure plasma spraying of NiAlMo powder and activation in aqueous alkali [70]. Reproduced by permission of Springer.

\section{Figure 4}

Tafel plots for hydrogen evolution at various coating materials in $4 \mathrm{M} \mathrm{NaOH}$ at $333 \mathrm{~K}$.

\section{Figure 5}

Steady state polarization curves recorded at various coating materials in $1 \mathrm{M} \mathrm{NaOH}$ at $353 \mathrm{~K}$ : (a) a mixed $\mathrm{Ni} / \mathrm{Fe}(\mathrm{OH})_{2}$ layer deposited from the sulfate solution using a cathodic current density of $0.25 \mathrm{~A} \mathrm{~cm}^{-2}$ for $50 \mathrm{~s}$; (b) $\mathrm{a} \mathrm{NiCo}_{2} \mathrm{O}_{4}$ spinel prepared thermally from a nitrate medium containing both $\mathrm{Ni}(\mathrm{II})$ and $\mathrm{Co}(\mathrm{II})$; (c) a mesoporous $\mathrm{Ni}(\mathrm{OH})_{2}$ layer; (d) a polished nickel microdisc and (e) a polished stainless steel microdisc [93]. Reproduced by permission of the Royal Society of Chemistry.

\section{Figure 6}

Cell voltage as a function of time over a 10 day period for an SPE cell with hydroxide conducting membrane. 


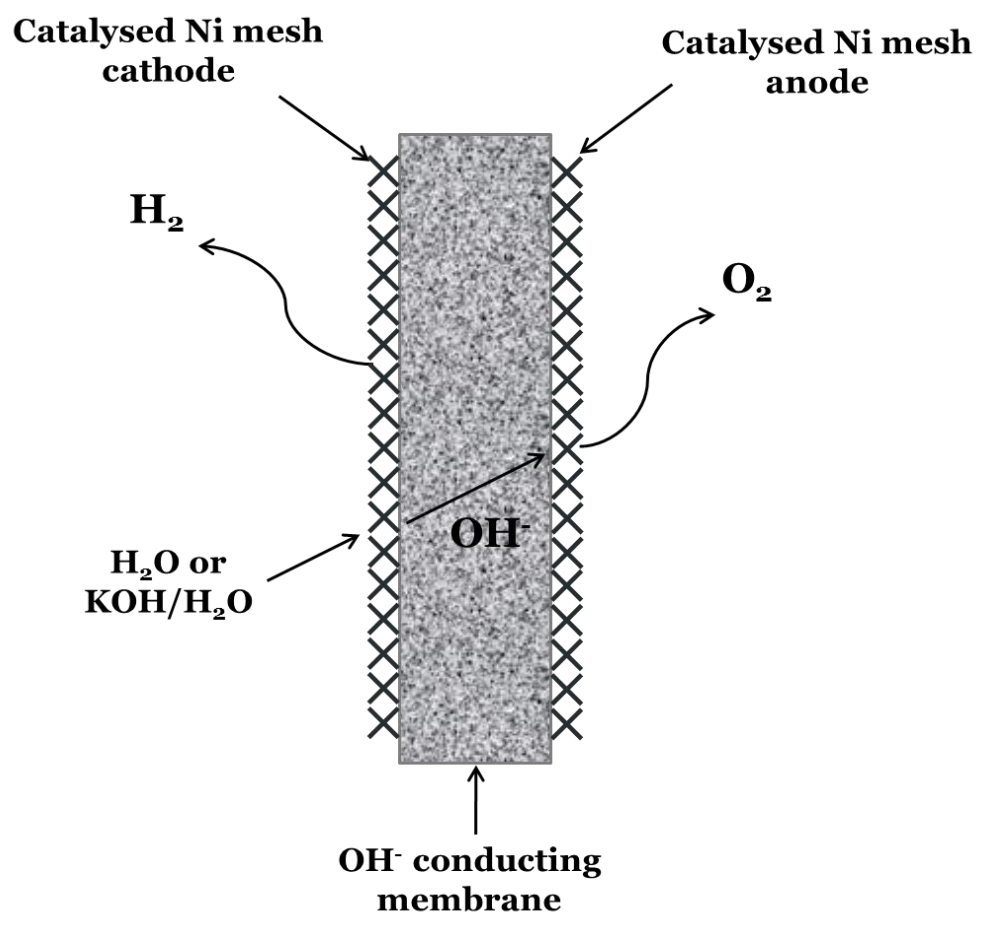

Fig. 1 


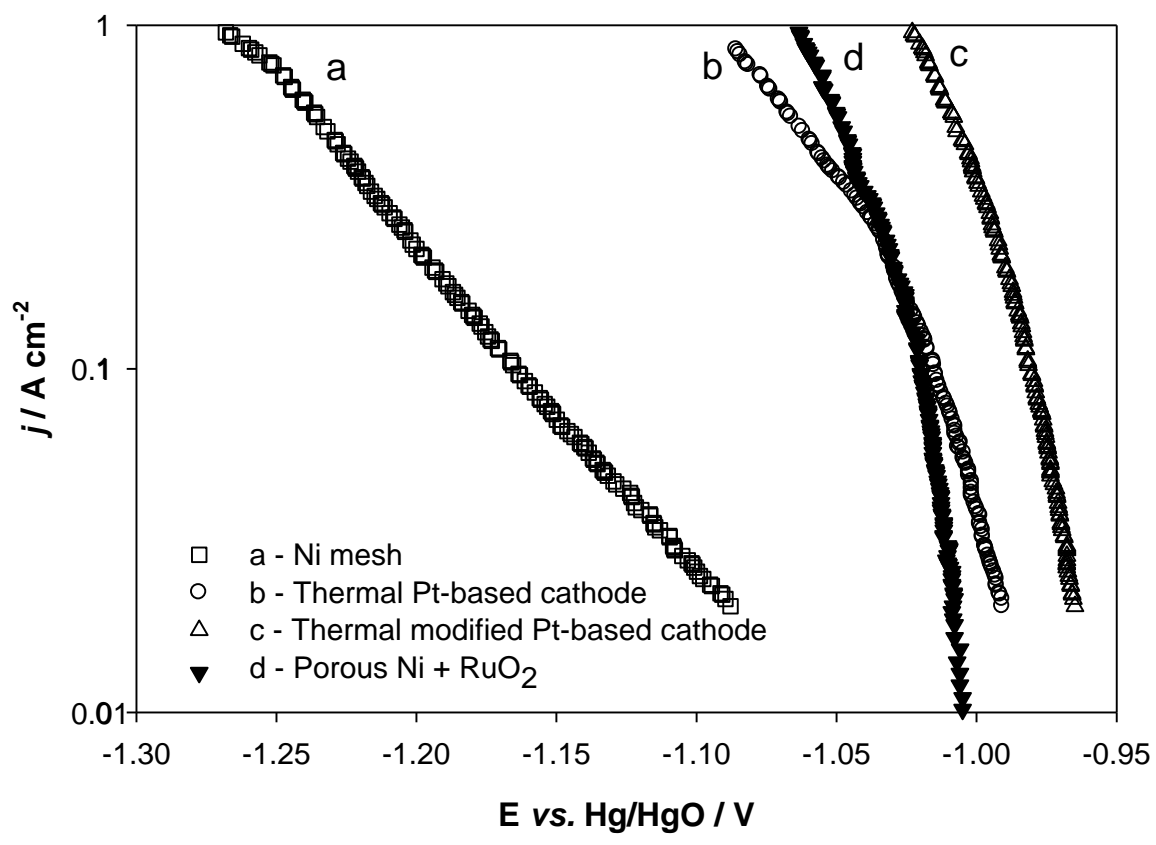

Fig. 2 


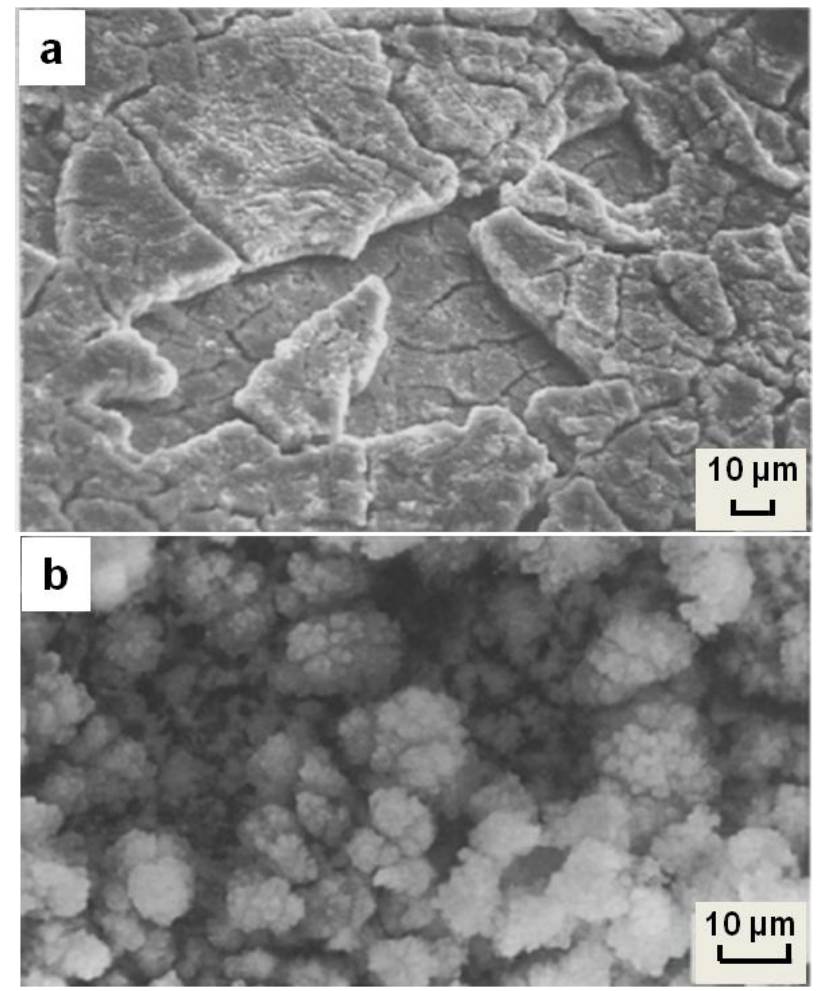

Fig. 3 


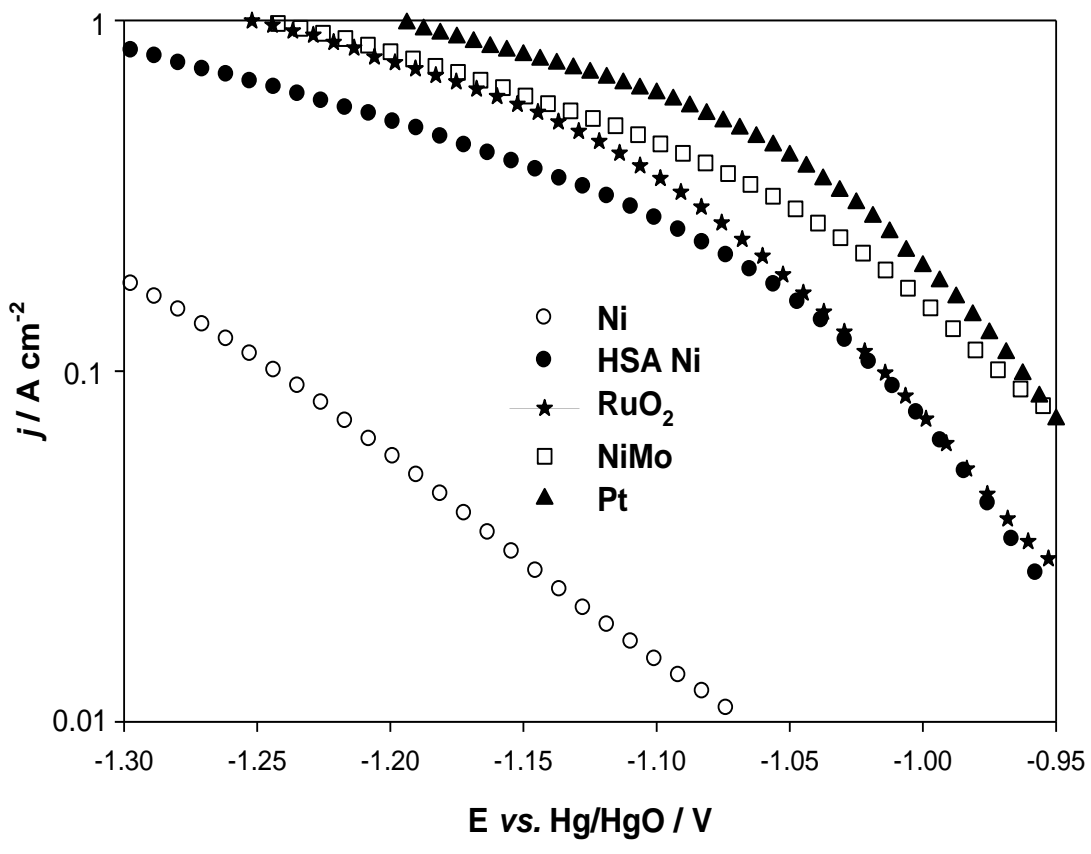

Fig. 4 


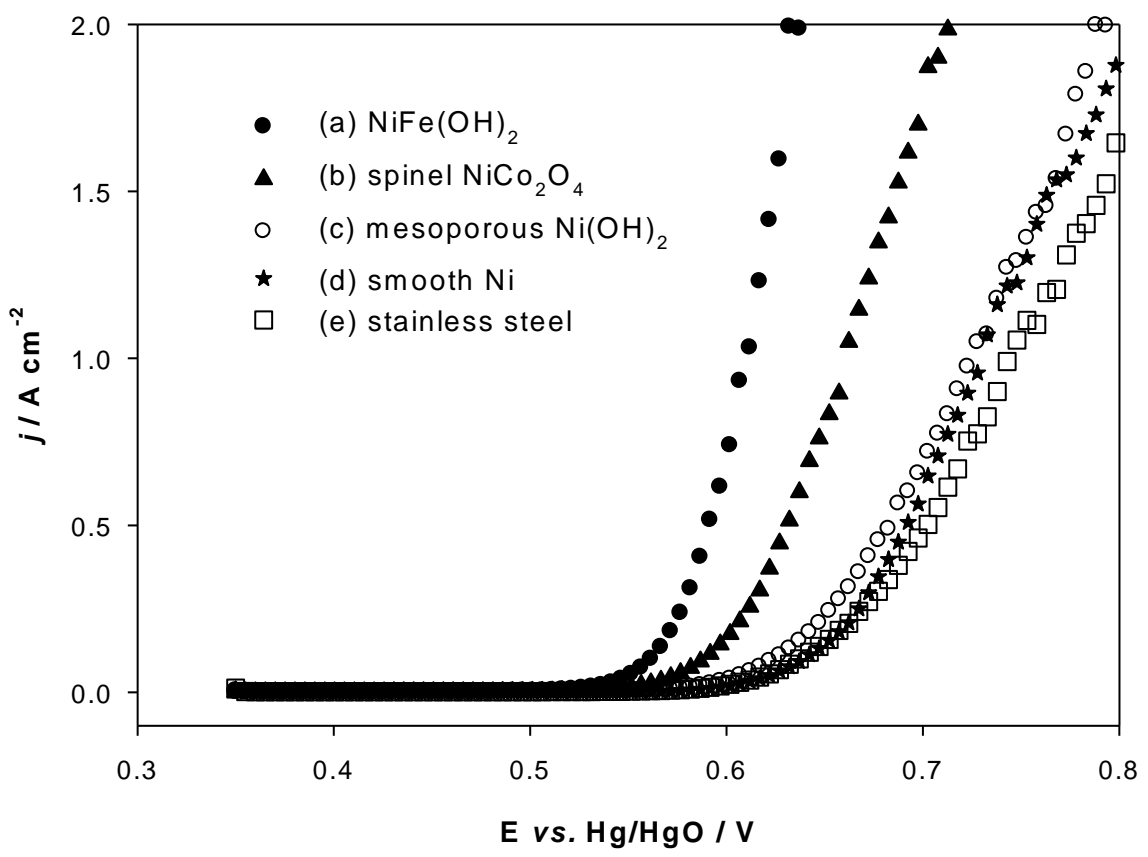

Fig. 5 


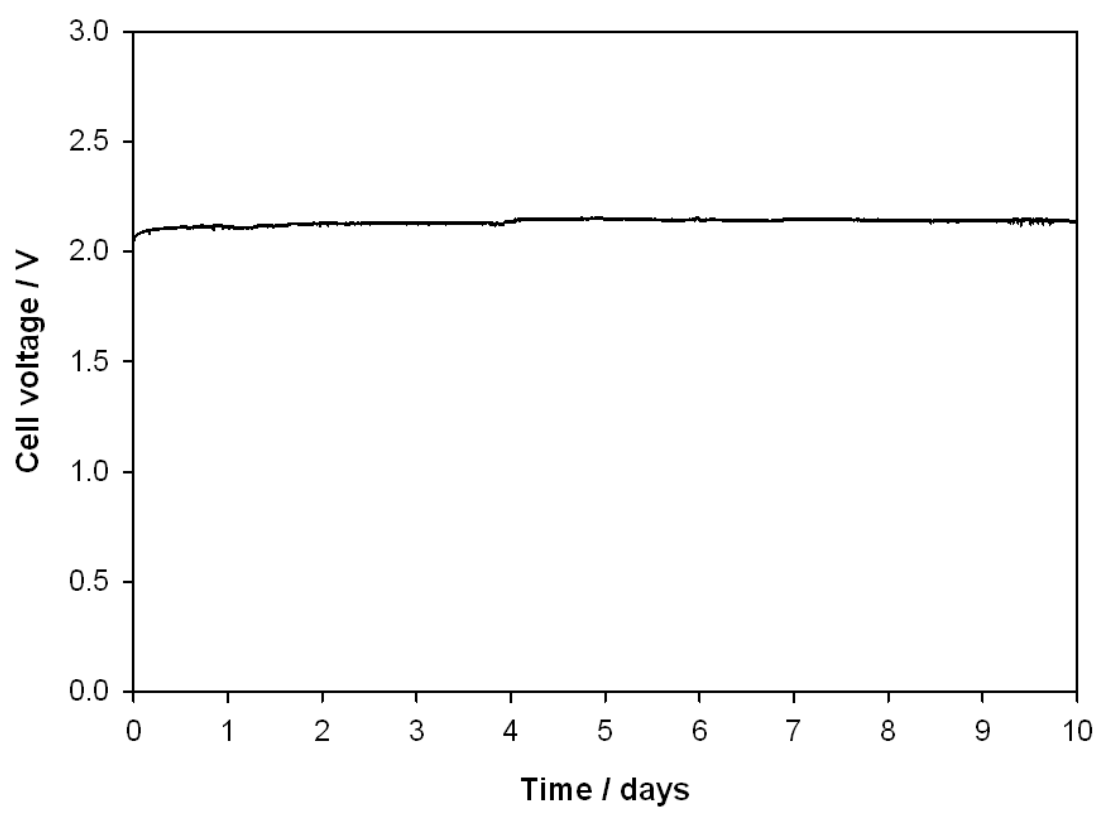

Fig. 6 